\title{
Dergiabant
}

Cilt/Volume: 9, Sayı/Issue: 1

(Mayıs/May 2021)

\section{Klasik Tefsir Hareketlerinin Mûsâ-Hızır Kıssası Bağlamında Mukayesesi}

\section{Comparison of Classical Interpretation Movements Within the Context of the Parable of Moses and al-Khidr}

\author{
Nazife Vildan Güloğlu \\ Dr. Öğr. Üyesi, Kastamonu Üniversitesi, illahiyat Fakültesi, \\ Kur'an-ı Kerim Okuma ve Kıraat İlmi Anabilim Dalı \\ Asst. Prof. Dr., Kastamonu University, Faculty of Theology, \\ Department of Quran Reciting and Qiraat Science \\ Kastamonu/Turkey \\ nguloglu@kastamonu.edu.tr \\ orcid.org/0000-0001-7126-7691

\section{Makale Bilgisi Article Information} \\ Geliş Tarihi: 3 Ocak 2021 \\ Yayın Sezonu: Bahar \\ Article Type: Research Article \\ Date Received: 3 January 2021 \\ Date Accepted: 17 May 2021 \\ Date Published: 30 May 2021 \\ Publication Season: Spring \\ https://doi.org/10.33931/abuifd.853127 \\ İntihal/Plagiarism
}

Makale Türü: Araştırma Makalesi

Kabul Tarihi: 17 Mayıs 2021

Yayın Tarihi: 30 Mayıs 2021

Bu makale özel bir yazılımla taranmış ve intihal tespit edilmemiștir.

This article has been scanned by a special software and no plagiarism detected.

\section{Atıf/Cite as}

Güloğlu, Nazife Vildan. "Klasik Tefsir Hareketlerinin Mûsâ-Hızır Kıssası Bağlamında Mukayesesi”. Dergiabant 9/1 (Mayıs 2021), 427-460. https://doi.org/10.33931/abuifd.853127

Copyright $\odot$ Published by Bolu Abant Izzet Baysal University Faculty of Theology, Bolu, 14030 Turkey. All rights reserved. https://dergipark.org.tr/tr/pub/dergiabant 


\title{
Klasik Tefsir Hareketlerinin Mûsâ-Hızır Kıssası Bağlamında Mukayesesi
}

\section{Öz}

İslâmî geleneğin dini yorumlama çabaları için beyan, irfan ve burhan olmak üzere üç ana te'vil yönteminden bahsedilebilir. Zikredilen bu üç genel yapının tefsir geleneğindeki yansımaları nasıldır? Bu makalede, Mûsâ-Hızır kıssası özelinde klasik tefsir hareketlerinin mukayese edilmesi hedeflenmiştir. Aynı doğrultuda müfessirlerin takip ettikleri yöntem ile yorum farklılıkları arasındaki ilişkinin tespit edilmesi de amaçlanmıştır. Bunun için de onların, kıssanın anlatıldığı Kehf sûresinin 60-82. âyetlerini nasıl yorumladıkları incelenmiștir. Her bir akımın önde gelen müfessirlerine ait izahlar, kategorize edilmiş ve bu esnada karşlaștırma yöntemi uygulanmıştır. Özellikle bu açıdan çalışmanın literatüre katkı sağlayacağı umulmaktadır. Klasik tefsirlerin ekseriyetle kıssayı bir kelamcı ve fıkıhçı bakış açısıyla yorumladıkları görülmüştür. Mesela kıssada geçen şahısların sıfatları ile ilgili yorumlar dahi daha çok Hızır'ın ortaya koyduğu faaliyetlerin Kelam ve Fıkıh İlmi çerçevesinde izahını mümkün kılmaya yöneliktir. Beyanî te'vil yöntemi kadar çok olmasa da bazı tefsirlerde irfânî te'vil yöntemine de başvurulmuştur. Sonuç olarak farklı ifade kategorisi ya da hitap şekillerine sahip Kur'ân pasajlarının, genellikle müfessirin takip ettiği yönteme göre izah edildiği müşahede edilmiştir.

Anahtar Kelimeler: Tefsir, Mûsâ-Hızır Kıssası, Beyanî Te'vil, İrfânî Te'vil, Kehf Sûresi.

\section{Comparison of Classical Interpretation Movements Within the Context of the Parable of Moses and al-Khị̂r}

\begin{abstract}
It can be mentioned that there are three main gloss methods as declaration, comprehension, and evidence in the efforts of Islamic tradition to interpret religion. What are the reflections of the mentioned three main systems in the interpretation tradition? In this article, classical gloss movements specific to Moses and al-Khidr parable are aimed to be compared. The relation between the methods that glossators follow and interpretation differences are also aimed to be identified in the same direction. Therefore, how they interpret the verses between $60^{\text {th }}-82^{\text {nd }}$ of Sürat al-Kahf, where the parable is told, is examined. The explanations of prominent glossators of each movement are categorized and comparison method is applied in the meanwhile. The study is expected to contribute to the literature especially in this respect. It is observed that classical interpretations mostly interpret the parable with a theologian and faqīh perspective. For example, even the interpretations about the attributes of the people in the parable are intended to explain rather the activities of al-Khiḍr in the frame of Kalām and Fiqh. Although it is not as many as Declaratory Gloss Method, Comprehensive Gloss Method has also been consulted in some interpretations. As a result, it is observed that Qur'ān passages that have different statement categories or ways of addressing are generally explained according to the method of the glossator.

Keywords: Interpretation, the Parable of Moses and al-Khiḍr, Declaratory Gloss Method, Comprehensive Gloss Method, Sūrat al-Kahf.
\end{abstract}

\section{Giriş}

İslâm toplumu gerek ilk vahiy pasajlarının tenzil ve tilaveti, gerekse $\mathrm{Hz}$. Peygamber'in fiilî rehberliği temelinde inşa edilmeye başlanmış; neticede kendi olarak varoluşunu gerçekleștirme sürecine girmiştir. İmam Şafiî (ö. 204/820) bu 
varoluş sürecini şu şekilde dile getirmektedir: “Ümmetin söylediklerinin tamamı Hz. Peygamber'in sünnetinin şerhi veya açıklamasıdır. Sünnet ise Kur'ân'ın şerhi veya açıklamasıdır. Kur'ân ise Esmâ-i Hüsnâ'nın şerhidir."1 Bu veciz sözün somut bir göstergesi olarak Kitap ve onu teybin ve tefsir eden sünnet merkezli bir gelenek vücut bulmuştur. İslâmî geleneğin dini yorumlama çabaları için beyan, irfan ve burhan olmak üzere üç ana te'vil yönteminden bahsedilebilir. Beyanî sistem, İslâm inancına hizmet eden bir âlem tasavvuru oluşturma amacındadır ve bu gayeye yönelik olarak nass, icmâ ve ictihadı otorite kaynaklar kabul eder. İrfanî sistem ise velayeti ve genel anlamda keşfi, irfanî bilginin biricik yolu kabul edip Allah ile bir çeşit birliğe ermeyi hedefler. Burhanî sistem de daha çok duyular, deney ve aklî muhakeme gibi insan aklının tabiî bilgi kaynaklarına dayanarak kâinatın bütününün ve parçalarının bilgisini elde etmeye çalışır. ${ }^{2}$

Yukarıda zikredilen üç genel yapıdan özellikle beyanî bilgi sisteminin tefsir geleneğine doğrudan etkileri olmuştur. Bunun sonucu olarak bir taraftan dil ile ilgili izahlara yer veren ancak daha çok âyetlerin tefsirine, nazil olduğu ortama ve muhataplara ilişkin Hz. Peygamber'den (s.a.s.), sahâbeden ve tâbiînden gelen rivayetleri toplayan tefsirler yazılmıştır. Taberî (ö. 310/923) ve İbn Kesîr (ö. 774/1373) tefsirleri gibi. Diğer taraftan ise ihtiyaç hissettiklerinde rivayet malzemesine de yer veren ancak âyetleri metinsel bağlamı ekseninde dilsel referanslardan hareketle te'vil eden tefsirler kaleme alınmıștır. Zemahșerî (ö. 538/1144) ve Râzî (ö. 606/1210) tefsirleri gibi. Burhanî sistemin izleri Râzî̀nin Mefâtîhu'l-gayb'ında görülse de onun tefsiri, daha çok beyanî sistem üzerine yürüyen bir te'vil hareketidir.

Âyetlerle ilgili işârî te'villerin tefsir olup olmadığına dair tartışmalar bir tarafa bırakılırsa, İslâmî gelenekteki irfanî yapının tefsir hareketlerine yansımaları bulunmaktadır. Kur'ân âyetlerini, farklı tonlamaları olmakla beraber, zâhir-bâtın ikilemi içinde ve bâtınî anlamı hedefleyerek, sûfînin seyrü sülûk tecrübesi neticesinde içine doğan sezgilerle (keşif ve ilhamla) yorumlayan işârî/tasavvufî tefsirler telif edilmiştir. et-Te'vîlâtü'n-Necmiyye ${ }^{3}$ isimli eser gibi.

Bu makalede her üç tefsir akımının öncüleri merkeze alınarak Mûsâ-Hızır kıssasının anlatıldığı Kehf sûresinin 60-82. âyetlerinin te'viline dair metinlerin tahlil

1 Bedruddîn Muhammed b. Abdillah ez-Zerkeșî, el-Bürhân fî 'ulûmi'l-Kur'ân, thk. Muhammed Ebü'l-Fadl İbrâhîm (Kahire: Dâru't-Türâs, ts.), 1/6.

2 Muhammed Âbid el-Câbirî, Arap-İslam Kültürünün Akıl Yapısı, çev. Burhan Köroğlu vd. (İstanbul: Kitabevi, 1999), 484.

Okuyan, et-Te'vîlâtü'n-Necmiyye'nin Necmeddîn-i Dâye'ye (ö. 654/1256) aidiyetinde şüphe olmadığını belirtmektedir. bk. Mehmet Okuyan, Necmuddin Daye ve Tasavvufi Tefsiri (Samsun: Ondokuz Mayıs Üniversitesi, Sosyal Bilimler Enstitüsü, Doktora Tezi, 1994), 256; Yine Okuyan tarafından yazılan TDV İslam Ansiklopedisi maddesinde 2006 itibariyle eserin neşredilmemiş olduğu ifade edilmiștir. bk. Mehmet Okuyan, "Necmeddîn-i Dâye", Türkiye Diyanet Vakfi İslâm Ansiklopedisi (Erişim 10 Temmuz 2020); et-Te'vîlâtü'n-Necmiyye'nin 2009 yllında yaplan baskısında ise Necmeddîn-i Kübrâ'ya (ö. 618/1221) nispet edildiği görülmektedir. bk. Necmeddîn el-Kübrâ, et-Te'vîlâtü'n-Necmiyye, thk. Ahmed Ferîd el-Mezîdî (Beyrut: Dâru'lKütübi'l-'Ilmiyye, 1430/2009), 1/1. Çalışmamızda bu neşir esas alınmakla birlikte zikri geçen ihtilaf dolayısıyla buradan sonra eserin müellifi belirtilmeyecektir. 
edilmesi; her bir akımın te'vildeki önceliklerinin, yorum farklılıklarının ve söz konusu âyetlere bakış açılarının gözler önüne serilmesi hedeflenmektedir. MûsâHızır kıssası, Kur'ân kıssaları arasında özellikle bir zâhir-bâtın kıssası olması hasebiyle öne çıkmaktadır ve tarihte olduğu gibi günümüzde de çok çeşitli yönlerden araştırmacıların dikkatini celp etmektedir.

Mûsâ-Hızır kıssası hakkında bilgi veren kaynaklar arasında hadis şerhleri ve bazı tarih kaynakları zikredilebilir. ${ }^{4} \mathrm{Bu}$ kıssanın içeriğiyle ilgili kitap, tez ve makaleler de kaleme alınmıştır. ${ }^{5}$ Bu makalede ise kıssanın, klasik tefsir kaynaklarına göre ele alınması söz konusu olacaktır. Aynı zamanda tefsirlerin kullandıkları yöntem çerçevesinde Mûsâ-Hızır kıssasını nasıl yorumladıkları ortaya konulmaya çalıșllacaktır. Çünkü bu konu, en detaylı șekliyle tefsir kaynaklarında anlatılmıștır. Netice itibariyle bu araştırma, kıssayı izah usulleri açısından müfessirlerin karşılaştırılmasını amaçlamaktadır. Çalışma, özellikle bu yönüyle diğer tez ve makale çalışmalardan ayrılmaktadır ve literatüre katkı sağlayacağı umulmaktadır.

\section{Genel Hatlarıyla Mûsâ-Hızır Kıssası}

Kur'ân-ı Kerîm'de adı verilmemekle birlikte müfessirler tarafından Hızır olduğu ifade edilen "kul” ile Hz. Mûsâ arasında geçen kıssa özetle şu şekildedir:

Bir vakit Hz. Mûsâ genç yardımcısına (Yûşâ b. Nûn) iki denizin birleştiği yere ulaşmaya karar verdiğini söyler. (Böylece iki denizin birleştiği yere (mecmau'lbahreyn) gitmek için yola koyulurlar.) Mecmau'l-bahreyne gelince azık olarak aldıkları balığı unuturlar, o da (mucizevi bir şekilde canlanarak denize atlar ve) denizde yol almaya başlar. Bir müddet sonra Mûsâ, genç yardımcısına 'azıklarını getirmesini' söyler. Genç adam, kayaya sığındıkları sırada balığı unuttuğunu, bunun kendisine şeytan tarafından unutturulduğunu ve balığın şaşılacak bir şekilde

4 Mesela bk. Ebû Muhammed Bedrüddîn el-Aynî, Umdetü'l-kâri fî şerhi Sahîhi'l-Buhârî, nșr. Abdullah Mahmûd Muhammed Ömer (Beyrut: Dâru'l-Kütübi'l-Ilmiyye, 1421/2001), 15/409413; 19/58-69; Ebû Ca'fer Muhammed b. Cerîr et-Taberî, Târîhu'lumem ve'l-mulûk, thk. Muhammed Ebu'l-Fadl İbrâhîm (Kahire: Dâru'l-Meârif bi-Mısr, 1387/1967), 1/376-226; Mutahhar b. Tâhir el-Makdisî, el-Bed' ve't-târîh (Kahire: Mektebetü's-Sekâfe ed-Dîniyye, ts.), 3/77-78.

5 Mesela bk. Necmeddin Bardakçı, "Îsmail Hakkı Bursevî’nin Musa-Hızır Kıssası Yorumunun İlimMarifet Uygunluğu Açısından Değerlendirilmesi", Süleyman Demirel Üniversitesi İlahiyat Fakültesi Dergisi 5 (1998), 81-103; Mustafa Öztürk, "Bilge Kul-Musa Kıssası ve İslam Kültüründe Hızır Mitosu, "Ondokuz Mayıs Üniversitesi Illâhiyat Fakültesi Dergisi 14-15 (2003), 245-281; Salih Sayın, Kelâm Açısından Kur'an ve Sünnette Hızır (Konya: Selçuk Üniversitesi, Sosyal Bilimler Enstitüsü, Yüksek Lisans Tezi, 2009), 1-93; Yasin Meral, "Mûsâ-Hızır Kıssası ve Kıssanın Yahudi Kökeniyle İlgili İddeaların Değerlendirilmesi", Ankara Üniversitesi İlahiyat Fakültesi Dergisi 55/2 (2014), 129-150; Ethem Cebecioğlu, "Niyaz-ı Mısrîye Göre Hz. Musa ve Hızır Kıssası: Çocuğun Öldürülmesi”, Akademiar Dergisi 1 (2016), 49-78; Muzaffer Barlak - Faruk Özdemir, "Mûsâ-Hızır Kıssasının Allah'ın İlkeli Bir Varlık Oluşu Çerçevesinde Değerlendirilmesi", Journal of Islamic Research 27/3 (2016), 353-371; Necmeddin Bardakçl, Hakikatin Keş̧fi Hz. Musa ve Hızır (İstanbul: Rağbet Yayınları, 2016), 1-144; Yusuf Kenan Atılgan, Ledünni İlmin Hz. MusaHızır Kıssası Bağlamında Kelami Açıdan Değerlendirilmesi (Sivas: Cumhuriyet Üniversitesi, Sosyal Bilimler Enstitüsü, Yüksek Lisans Tezi, 2017), 1-100; Sevim Arslan, "Hz. Musa ve Hızır Kıssası Üzerine Bir Değerlendirme”, Toplum Bilimleri Dergisi, 12/24 (Temmuz 2018), 161-176; Zeynep Temel, Kur'ân'daki Musa-Hızır Kıssasının İbnü'l-Arabî Yorumu (İstanbul: 29 Mayıs Üniversitesi, Sosyal Bilimler Enstitüsü, Yüksek Lisans Tezi, 2020), 1-133. 
denizde yol aldığını, beyan eder. Hz. Mûsâ, bu durumu aradıkları kişiyle ilgili bir işaret olarak algllar ve izlerini takip ederek geri dönerler. Böylece Allah'ın katından bir rahmet bahşettiği ve ilim verdiği bir kul (Hızır) ile buluşurlar. ${ }^{6}$ (Bu buluşmadan itibaren kıssa Mûsâ ile Hızır arasında devam etmektedir.)

Hz. Mûsâ bu kuldan, kendisine bahşedilen ilimden öğretmesi için ona tabi olmak istediğini söyler. Bu kul, Hz. Mûsâ'ya iç yüzüne vakıf olamayacağı şeyler sebebiyle kendisiyle beraberliğe sabredemeyeceğini belirtirse de Hz. Mûsâ Allah'ın izniyle sabırlı olacağını ve ona karşı gelmeyeceğini belirterek ısrar eder. Bunun üzerine (Hızır), meydana gelen olaylar hakkında açıklama yapmadığı sürece $\mathrm{Hz}$. Mûsâ'nın kendisine soru sormamasını şart koşarak teklifini kabul eder. Böylece (bu iki seçkin kulun) yolculukları başlar. Bir gemiye binerler, (Hızır) gemiyi deler. Bunun üzerine Hz. Mûsâ, (Hızır'a) "Halkını boğmak için mi onu deldin? Gerçekten sen (ziyanı) büyük bir iş yaptın." der. Buna karşılık (Hızır) "Ben sana, benimle beraberliğe sabredemezsin, demedim mi?" diyerek Mûsâ’ya koștuğu şartı hatırlatır. $\mathrm{Bu}$ ilk aşamada Hz. Mûsâ, verdiği sözü unuttuğunu söyleyerek özür beyanında bulunur. Daha sonra tekrar yola koyulurlar. Nihayet bir oğlan çocuğuna rastlarlar ve Hızır onu öldürür. Bunun üzerine Hz. Mûsâ "Tertemiz bir canı, kimseyi öldürmediği halde katlettin ha! Gerçekten sen fena bir şey yaptın!” diyerek itiraz eder. Hızır da ona "Ben sana, benimle beraberliğe sabredemezsin, demedim mi?" diyerek kendisiyle beraberliğe sabredemeyeceğini tekrar hatırlatır. Buna karşılık Hz. Mûsâ "Bundan sonra sana bir şey sorarsam artık bana arkadaşlık etme." diyerek son bir fırsat ister. Böylece tekrar yola koyulurlar. Nihayet bir şehre varıp o şehir halkından yiyecek isterler ama ahali onları misafir etmez. Bu sırada (Hızır) orada yıkılmaya yüz tutmuş bir duvar görür ve onu onarır. Bu duruma şahit olan Hz. Mûsâ, "İsteseydin buna karşılık ücret alabilirdin" der. Bu son konuşma, diğerlerinden farklı da olsa bardağı taşıran son damla olmuştur. Bunun üzerine (Hızır), ayrılık vaktinin geldiğini söyler ve Hz. Mûsâ'ya sabır gösteremediği davranışların te'vilini açıklayacağını ifade eder. ${ }^{7}$

Hızır'ın beyan ettiği ilk te'vil, gemiyle ilgili olup şu şekildedir: “Gemi, denizde çalışan birtakım yoksul kimselere aitti ve ilerde gemileri gasp eden bir kral vardı. Onu kusurlu hale getirmek suretiyle gasptan kurtarmak istedim." Çocukla ilgili olan te'vil ise şöyledir: "Çocuğa gelince, onun ana babası, mümin kimselerdi. Bunun için (çocuğun) onları azgınlık ve nankörlüğe sevk etmesinden korktuk ve istedik ki, Rableri onun yerine kendilerine, ondan daha temiz ve daha merhametlisini versin." Son te'vil, duvarla ilgili olarak şu şekilde ifade edilmiştir: "Duvara gelince, șehirde iki yetim çocuğun idi; altında da onlara ait bir hazine vardı; babaları ise iyi bir kimse idi. Rabbin istedi ki, o iki çocuk güçlü çağlarına erişsinler ve Rabbinden bir rahmet olarak hazinelerini çıkarsınlar. Ben bunu da kendiliğimden yapmadım. İşte, hakkında sabredemediğin şeylerin iç yüzü budur."8

bk. Kur'ân Yolu (Erişim 10 Nisan 2020), el-Kehf 18/60-65.

el-Kehf 18/66-78.

el-Kehf 18/79-82. 
Mûsâ-Hızır kıssası, Kehf sûresinde anlatılmaktadır. Bu sûre, tıpkı bu kıssa gibi müteşâbih ve ilginç olan iki kıssayı daha barındırmaktadır. Bunlardan birincisi bir grup gencin mağaraya sığınmalarının anlatıldığı Ashâb-ı Kehf kıssası, diğeri ise Zülkarneyn kıssasıdır. Bu kıssaların üçünde de Allah'ın büyük lütuflarda bulunduğu bazı kişilere, kendi katından rahmet ve özel yetkiler verdiği vurgulanmaktadır. ${ }^{9}$

Kur'ân'da Hz. Mûsâ'nın genç (fetâ) ile yaptığı seyahate ne zaman ve niçin çıktığı anlatılmadığı gibi bu seyahatin ne kadar sürdüğü de açılanmamıştır. Müfessirlerin Yûşa' b. Nûn olarak ifade ettikleri ve Hz. Mûsâ'nın hizmetinde olduğunu beyan ettikleri bu gencin kimliği de Kur'ân'da müphem bırakılmıştır. ${ }^{10}$ Kehf sûresinde, Hz. Mûsâ'nın Hızır ile gerçekleşen buluşmasından bahsedilen âyetten ${ }^{11}$ itibaren ise ondan söz edilmediği görülmektedir.

Seyyid Kutub'un (ö. 1966) ifadesiyle bu kıssa, aniden gerçekleşen gaybî olaylarla kuşatılmış gizemli bir kıssadır.12 Kıssada Mûsâ ile Hızır'ın buluşma ve tanışmaları, balığın kaybolması simgesine bağlanmış; bu şekilde anlatıma daha baştan itibaren sembolik bir boyut kazandırılmıştır.

Hz. Mûsâ, kendisine kitap verilen ve ülü'l-azm olduğu ifade edilen peygamberlerdendir. ${ }^{13}$ Kur'ân-ı Kerîm'de en çok zikri geçen peygamber olan Hz. Mûsâ, otuz dört sûrenin 136 yerinde yâd edilmektedir. ${ }^{14}$ Kehf sûresinin ilgili âyetlerinde Hızır'a verildiğinden bahsedilen rahmet ve ilim, hangi boyuttadır ki Hz. Mûsâ'nın belli bir zaman diliminde kendisine tabi olmasını sağlamıştır. Âyetteki "jرْمَ/rahmeten" ifadesi, diğer kullanımlarıyla da desteklenmek suretiyle çoğu müfessir tarafından "nübüvvet" olarak tefsir edilmiştir. ${ }^{15} \mathrm{Bu}$ ifadenin akabinde

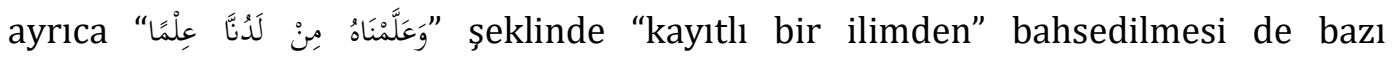
müfessirlerin dikkatini çekmiş ve kıssanın içeriği bu ifadeye odaklı olarak çözümlenmeye çalışılmıştır. ${ }^{16}$

Kıssayı diğer Kur'ân kıssalarından farklı kılan hususlardan biri de Hızır'ın daha yolculuk başlamadan neticeyi haber vermesi ve Hz. Mûsâ'ya kendisine sabredemeyeceğini bildirmesidir. Bu durum kıssayı, işârî te’vile açık bir hale

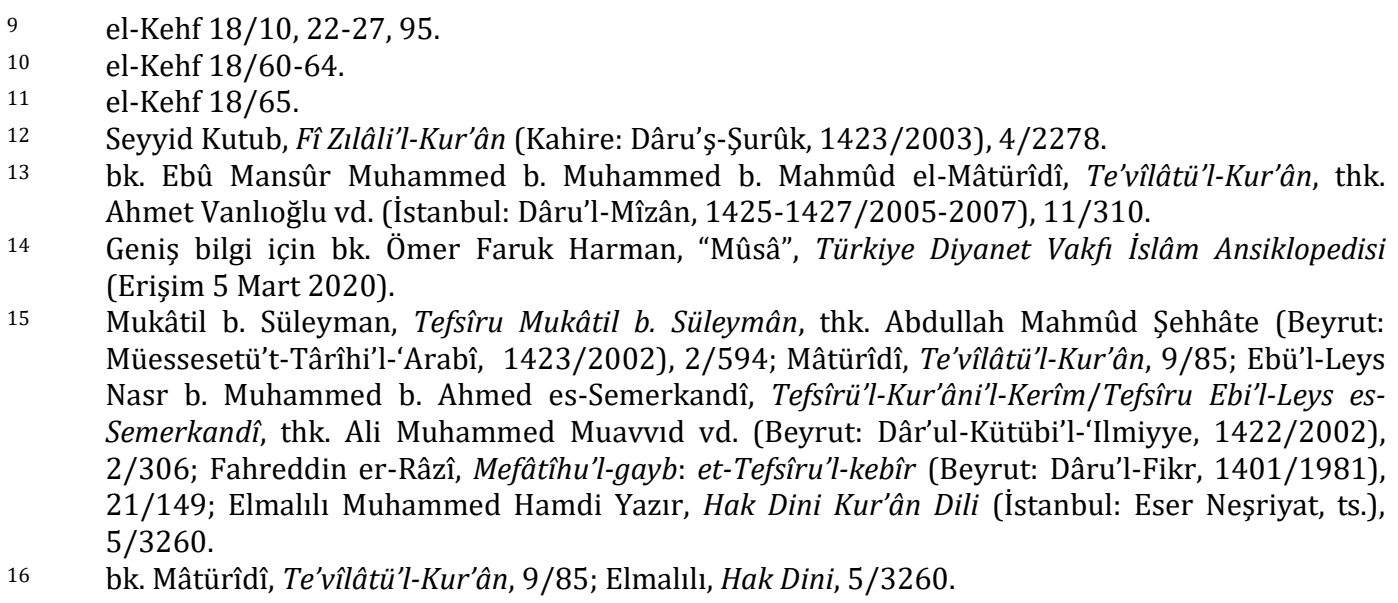


getirmektedir. İlgili âyette Hz. Mûsâ'nın iç yüzüne vakıf olamayacağı bir bilgiden bahsedilmesi dikkat çekicidir. Bu bilgi nasıl bir bilgidir ki ülü'l-azm bir peygamber henüz tecrübe etmemiştir? Bir diğer önemli konu ise bu kıssanın sonunda Hızır'ın yaptığı fiillerin kendi iradesiyle olmadığını dile getirerek şöyle demesidir: مَمَا فَعَلُُْهُ عَنْ آْمرى “Bütün bunları ben kendi görüşümle yapmış değilim.”17 İmam Mâtürîdî (ö. 333/944), Hızır'ın son olarak söylediği bu ifadeyi önceden söylediği إنَّكَ لَنْ تَسْتَطيعَ مَعِيَ صَصْبر "Doğrusu sen benimle beraberliğe sabredemezsin." şeklindeki sözünün te'vili olarak açıklamaktadır.18 Yine dikkat çekici bir husus da Hz. Mûsâ'nın peşine düştüğü bilgiyi elde etmenin ilk şartının "soru sormamak" olmasıdır. Hâlbuki soru sormak, ilmin anahtarı olarak nitelenmektedir. Hızır kıssasının yapısal farklılığına vurgu yapan bir diğer nokta da Hızır'ın te'vil kavramına yüklediği anlamdır. Burada te'vilin, Kur'ân'daki diğer kullanımlarından farklı bir şekilde, "hadiselerin arka planı hakkında bilgi verme" anlamında kullanıldığı görülmektedir. ${ }^{19}$

Muhteva olarak tanıttığımız Hz. Mûsâ ile Hızır'ın yol arkadaşlığı, daha başından itibaren sırlarla yüklü gözükmektedir ve gizemli yapısıyla öne çıkmaktadır. Zira daha kıssanın başında Hızır lakabı dahi telaffuz edilmemiş ve onun hakkında sadece "عَبْدًا مِنْ عِبََادِنَا kullarımızdan bir kul”20 ifadesi kullanılmıştır. Mûsâ-Hızır kıssası, Yûsuf sûresi istisna edilirse, Kur'ân'da peygamberlerle ilgili anlatılan kıssalardan bâtınî boyutuyla ayrılmaktadır. Bu noktaya dikkat çeken Elmalılı (ö. 1942), MûsâHızır kıssasının bir zâhir-bâtın kıssası olduğunu ifade etmekte ve bu bağlamda Hızır meselesinin konusu itibariyle bâtına ait olduğunu belirtmektedir. Bu sebeple Elmalılı'nın, klasik tefsirlerde geçen "iki denizin birleştiği yer" ile ilgili rivayetleri zikrettikten sonra, bu konuda sûfiyyenin "iki ilim denizi olan Mûsâ ile Hızır'ın birleştiği yer" yorumunu, Zemahşerî gibi müfessirlerce tenkit edilmesine rağmen, ${ }^{21}$ daha yerinde ve daha doğru bulduğu görülmektedir. Aynı şekilde onun, Hızır’ın hayatıyla ilgili rivayetleri ve ilgili tartışmaları zikrettiği yerde, "bu konuda sûfiyyeden nakledilen kelamları, zâhiri üzere münakaşa etmemek gerektiğini” belirttiği ve "Hızır'ın vücudu, âlem-i misaldedir." yorumunu tercih ettiği müşahede edilmektedir. ${ }^{22}$

\section{Klasik Tefsir Geleneğinin Mûsâ-Hızır Kıssasıyla İlgili Te’villeri}

Beyanî te'vilin bazı temsilcileri, Kur'ân kıssalarındaki ihbârî ifade tarzlarını, birer inşâi hitap biçimi olarak okumak suretiyle itikadî ve fikhî esaslar ve hükümler istinbat etmişlerdir. Söz gelimi Yûsufu kuyuya atarak ölüme terk eden kardeşlerin

el-Kehf 18/82.

Mâtürîdî, Te'vîlâtü'l-Kur'ân, 9/96.

bk. Nâsırüddîn Ebû Saîd Abdullah b. Ömer el-Beyzâvî, Envâru't-tenzîl ve esrâru't-te'vîl (Dâru İhyâi't-Türâsi'l-'Arabî, Beyrût ts.), 3/290.

el-Kehf 18/65.

Mahmûd b. Ömer ez-Zemahșerî, el-Keşşâff 'an hakâ'ikı gavâmizi't-tenzîl ve 'uyûni'l-ekâvîl fî vücûhi't-te’vîl, nşr. Halîl Me'mûn Şeyhâ (Beyrut: Dârü'l-Ma'rife, 1430/2009), 624. 
babalarına yalan söylemelerinin anlatıldığı âyet pasajlarından hareketle büyük günah işleyenin tekfir edilemeyeceği sonucu çıkarılırken,23 Mûsâ ile Hızır'ın bindikleri geminin sahipleri olarak zikredilen "mesâkîn" tabirinden hareketle İmam Şafiî zekâtın mesârifi kapsamındaki miskin kavramının tarifini yapmıştır. ${ }^{24}$ Buna mukabil bir sufî müfessir ise Hac ibadetinde, Safa ve Merve arasındaki sa'yin yapılmasını talep eden ahkâm âyetini şöylece yorumlamaktadır: Safa vücûdü'l-kalp, Merve de vücûdü'n-nefstir. Şeâirillah ise bir yönüyle yakîn, tevekkül, rıza ve ihlas gibi kalbî menâsiktir; bir yönüyle de sabır, şükür ve zikir gibi nefsî menâsiktir. Bunların tamamı da Allah'ın dininin alemlerini yani şeâirini meydana getirir. Beytin ziyaret edilmesi (haccedilmesi) ise vahdet makamına tam bir fena ile ulaşmaktır. ${ }^{25}$ Anlaşılacağı üzere farklı ifade kategorisi ya da hitap şekillerine sahip Kur'ân pasajları, müfessirin takip ettiği yöntem çerçevesinde yorumlanmaktadır. Aynı hükmü, Mûsâ-Hızır kıssası için de genellemek ne kadar doğrudur? Bu sorunun cevabını verebilmek için klasik tefsir eserlerinde konuyla ilgili âyetlerin nasıl te'vil edildiğine bakmak gerekir.

\section{1. Hz. Mûsâ ve Fetâ'nın Yolculuğa Çıkmaları ve Hızır'la Buluşmaları}

Kıssanın anlatıldığı âyetlerin ilk bölümü sayılabilecek Kehf sûresinin 60-65. âyetlerinde, Hz. Mûsâ ile fetâsının yolculuğa çıkmaları ve bu esnada başlarına gelen bazı ilginç olaylar anlatılmaktadır. Buna göre Hz. Mûsâ, genç adamına "iki denizin birleștiği yere varıncaya kadar durup dinlenmeyeceğini, gerekirse senelerce yürüyeceğini" ifade etmiş, böylece yolculuğa çıkmışlar, iki denizin birleștiği yerde balıklarını unutup gitmişler ve neticede oraya tekrar dönüp Allah'ın katından rahmet bahşettiği kulu bulmuşlardı.

Bu bölüm ile ilgili olarak tefsirlere bakıldığında bazı noktaların öncelikle ele alındığı ve çeşitli sorulara cevaplar arandığı görülmektedir. Bu sorular, şu şekilde sıralanabilir: Kıssada anlatılan Mûsâ hangi Mûsâ'dır? Hz. Mûsâ ile yolculuk yapan fetâ kimdir? Hz. Mûsâ'nın fetâya yolculuğa başlamadan söylediği sözler, ne ifade etmektedir? İlgili âyette, "kullarımızdan bir kul" denen şahıs kimdir? Veli mi nebi mi, yoksa melek midir? İki denizin birleștiği yer neresidir?26 Zikri geçen sorulara verilen cevaplar ise şu şekilde özetlenebilir:

\section{1. 1. Hz. Mûsâ'nın Kimliği}

Tefsirlerde incelenen ilk mesele, kıssada bahsedilen Mûsâ'nın İsrâîloğulları'nın Mûsâ'sı olup olmadığı hususudur. Hâlbuki bu soru, sahabe zamanında da gündeme getirilmiş ve neticede İbn Abbas tarafından nakledilen bir

Mâtürîdî, Te'vîlâtü'l-Kur'ân, 7/283-284.

Fahreddin er-Râzî, Mefâtîhu'l-gayb, 21/161.

İsmâil Hakkı Bursevî, Rûhu'l-beyân (İstanbul: el-Matbaatü'l-Osmâniyye, 1330/1911), 5/264.

Ferrâ el-Begavî, Mecâlimü't-tenzîl, thk. M. Abdullah en-Nemr vd. (Riyad: Dâru Tayyibe, 1409/1988), 5/187; Zemahșerî, el-Keșşâf, 624; Fahreddin er-Râzî, Mefâtîhu'l-gayb, 21/146-147. 
rivayetle cevabını almıştı. ${ }^{27}$ Yine de bazı müfessirler, bu konuya temas etmişler ve çoğunlukla burada zikredilen Mûsâ'nın kendisine Tevrat verilen Mûsâ b. İmrân olduğunu beyan etmişlerdir. Çünkü özellikle Yahudiler, bu kıssada bahsedilen Mûsâ'nın Mûsâ b. Mîşâ olduğunu iddia etmektedirler. ${ }^{28}$ Taberî ve İbn Kesîr gibi müfessirler, bu konuyla ilgili izah getirme ihtiyacı hissetmezken ${ }^{29}$ çoğu tefsirde konunun gündeme getirildiği görülmektedir. Mesela Mâverdî (ö. 450/1058), cumhura göre âyette geçen Mûsâ'nın Mûsâ b. İmrân olduğunu, ifade etmektedir. ${ }^{30}$

Râzî de zikri geçen meseleyi detaylı bir şekilde ele almıștır. Râzî’nin beyanına göre Kaffâl (ö. 365/976), Kur'ân'da mutlak olarak bahsedilen Mûsâ ismiyle Hz. Mûsâ'nın kastedildiğini ifade etmekte ve bunu dildeki kullanımlardan da deliller getirerek ispatlamaktadır. Nitekim dilde bir isim zikredildiği zaman öncelikle o isimle meşhur olan zat hatıra gelmektedir. Başka biri kastediliyorsa o kimse bir sıfatıyla zikredilmeli ve böylece belirli hale getirilmelidir. ${ }^{31}$ Kaffâl'ın da vurguladığı üzere ilgili âyetlerde Mûsâ ismi tek başına zikredildiğine göre bu kimse, Mûsâ b. İmrân olmalıdır.

\section{1. 2. Fetâ'nın Kimliği}

Kehf sûresinin 60-65. âyetlerinin tefsiri sırasında ele alınan diğer bir konu, âyette geçen fetânın kim olduğu ve Hz. Mûsâ'nın yanında ne sıfatla bulunduğu meselesidir. Mukâtil'e (ö. 150/767) göre bu kimse, Yûsuf b. Ya'kûb'un torunlarından olup Hz. Mûsâ'nın kız kardeșinin oğlu olan Yûşa' b. Nûn'dur.32 Zeccâc (ö. 311/923) ise burada bahsedilen kimsenin, Hz. Mûsâ'ya hizmet eden bir şahıs olduğunu ve bu sebeple kendisine fetâ denildiğini ifade etmektedir. Ayrıca âyette geçen "Bize kuşluk yemeğimizi getir!” şeklindeki hitabın da buna işaret ettiğini belirtmektedir. ${ }^{33}$ Mâtürîdî de bazı müfessirlerin bu kimsenin Hz. Mûsâ'nın hizmetkârı olduğunu ve ona hizmet eden anlamında bu kimseye fetâ denildiğini ifade ettiklerini, bazılarının da onun Hz. Mûsâ'ya tabi olan ve ondan ilim öğrenmek için beraberinde bulunan bir

27 Saîd b. Cübeyr, şöyle demiștir: Ben İbn Abbas'a, Nevf el-Bikâlî, (Hızır'ın sahibi olan) Mûsâ İsrâîloğulları'nın Mûsâ'sı değildir; o ancak başka bir Mûsâ'dır iddiasında bulunuyor, dedim. Bunun üzerine İbn Abbas, Allah'ın düşmanı yalan söylemiştir, dedi. bk. . Ebû Abdillâh Muhammed b. İsmail el-Buhârî, el-Câmi'u's-sahîh, nşr. Bedreddin Çetiner (İstanbul: Çağrı Yayınları, 1413/1992), “'Ilim”, 44; Ayrıca bk. Ebû Abdillâh Ahmed b. Muhammed b. Hanbel eşŞeybânî Ahmed b. Hanbel, el-Müsned, nșr. Bedreddin Çetiner (İstanbul: Çağrı Yayınları, 1413/1992), 5/117-119; Buhârî, "Enbiyâ"”, 27; "Tefsîr", 18/3; Ebü'l-Hüseyn Müslim b. el-Haccâc Müslim, el-Câmi'u's-sahîh, nșr. Bedreddin Çetiner (İstanbul: Çağrı Yayınları, 1413/1992), "Fezâ'il”, 170-173; Ebû Îsâ Muhammed b. Îsâ et-Tirmizî, Sünenü't-Tirmizî, nşr. Bedreddin Çetiner (İstanbul: Çağrı Yayınları 1413/1992), "Tefsîr", 19/1.

28 Fahreddin er-Râzî, Mefâtîhu'l-gayb, 21/144.

29 Taberî, Câmi'u'l-beyân, 15/271; Imâdüddîn Ebü'l-Fidâ İsmail b. Kesîr, Tefsîrü'l-Kur'âni'l-'azîm, thk. Mustafa Seyyid Muhammed vd. (Kahire: Mektebetü Evlâdi'ş-Şeyh li't-Türâs, 1421/2000), 9/161.

30 Ebü'l-Hasen Alî b. Muhammed b. Habîb el-Basrî el-Mâverdî, en-Nüket ve'l-'uyûn, nşr. Seyyîd b. Abdülmaksûd b. Abdürrahîm (Beyrut: Dâru'l-Kütübi'l-'Ilmiyye, ts.), 3/321.

Fahreddin er-Râzî, Mefâtîhu'l-gayb, 21/145.

Mukâtil b. Süleyman, Tefsîru Mukâtil b. Süleymân, 2/592.

Ebû İshâk İbrâhîm b. es-Serî el-Bağdâdî ez-Zeccâc, Me'âni'l-Kur'ân ve i'râbüh, thk. Abdülcelîl Abdüh Şelebî (Beyrut: Âlemü'l-Kütüb, 1408/1988), 3/299. 
kimse olduğunu söylediklerini dile getirmektedir. ${ }^{34}$ Zemahşerîye (ö. 538/1144) göre de burada geçen fetâ kelimesi, abd/köle anlamındadır zira Hz. Peygamber'in "Sizden biriniz gencim desin kölem/kulum demesin!" 35 șeklindeki buyruğu, bu izaha delil teşkil etmektedir. Zemahşerî, "Buradaki fetâ, Yûşa' b. Nûn'dur; Hz. Mûsâ'ya tabi olduğu ve onun hizmetinde bulunduğu için kendisine fetâ/genç denmiştir." şeklinde bir görüş olduğunu da zikretmektedir. ${ }^{36}$

\section{1. 3. Hz. Mûsâ'nın Sözü}

Kehf sûresinin 60. âyetinde geçen, Hz. Mûsâ'nın "Durup dinlenmeyeceğim; ta iki denizin birleștiği yere kadar varacağım yahut senelerce yürüyeceğim." mealindeki beyanı da müfessirlerin ilgisini çekmiştir. Konuyla ilgili olarak Taberî, Arap dilini bilen âlimlerden bir kısmına göre âyette geçen حُقُبْ/hukub kelimesinin "bir yıl" demek olduğunu, beyan etmiştir. Ayrıca bu kelimenin "seksen yıl" veya "yetmiş yll" ve hatta "bir asır" anlamına geldiğini ifade edenlerin de bulunduğunu nakletmiştir. ${ }^{37}$

Râzîye göre bu beyan, Hz. Mûsâ'nın ilmi elde etmek amacıyla bu yolculuğundaki büyük sıkıntı ve güçlüklere katlanacağını kendi kendine telkin ettiğinin ve bu hale yoğunlaştığının bir ifadesidir. Burada dikkat çekilen bir mesele de şudur: İlim elde etmek isteyen kimse, tek bir mesele için bile, gerekirse doğudan batıya yolculuk yapar. ${ }^{38}$ Kurtubî (ö. 671/1273) de âyette geçen beyana "Kesintisiz olarak yürümemi sürdüreceğim." veya "Senden hiç ayrılmayacağım." şeklinde anlamlar verildiğini söylemiştir. ${ }^{39}$ Nihayetinde ilgili beyanlar, fazilet sahibi ve âlim kimselerle karşılaşma fırsatının, onların bulundukları bölgeler uzak da olsa, ganimet bilinmesi gerektiğini göstermekte ${ }^{40}$ ve ilim taliplerini bu yolda kararlı olmaya davet etmektedir.

\section{1. 4. "Kullarımızdan Bir Kul" Denen Şahıs ve Sıfatı}

Müfessirler, bu şahsın Hızır olduğu konusunda hemfikirdirler. Görüşüne itibar edilmeyen bazı kimseler buna muhalefet etmişlerse de bu doğru bulunmamıştır. ${ }^{41}$ Çünkü Hz. Peygamber'den gelen rivayetler de o şahsın Hızır olduğunu bildirmektedir. ${ }^{42}$

Mâtürîdî, Te'vîlâtü'l-Kur'ân, 9/80.

Buhârî, "'Itk", 17/3.

Zemahșerî, el-Keşşâff, 624 .

Ebû Ca'fer Muhammed b. Cerîr et-Taberî, Câmi'u'l-beyân 'an te'vîli âyi'l-Kur'ân (Beyrut: Dârü'lFikr, 1408/1988), 15/272; Ebû Abdullah Muhammed b. Ahmed el-Kurtubî, el-Câmi' li-ahkâmi'lKur'ân, thk. Abdullah b. Abdulmuhsin vd. (Beyrut: Müessesetü'r-Risâle, 1427/2006), 13/316; İbn Kesîr, Tefsîrü'l-Kur'ân, 9/161.

38 Fahreddin er-Râzî, Mefâtîhu'l-gayb, 21/147.

39 Kurtubî, el-Câmi', 13/315-316.

$40 \quad$ Kurtubî, el-Câmi', 13/318.

41 Kurtubî, el-Câmi', 13/324; Mâtürîdî ise Te'vîlât'ında bu zatın Hızır olduğu konusunda te'vil ehlinin icmâ ettiğini söylemekle birlikte, Kur'ân'da "Hızır" ifadesinin geçmediğini ve ona sadece "kullarımızdan bir kul" dendiğini vurgulamıştır. bk. Mâtürîdî, Te'vîlâtü'l-Kur'ân, 9/84.

Mesela bk. el-Buhârî, “'ilim”, 44; Müslim, “Fezâ'il”, 170-173; Tirmizî̀, “Tefsîr”, 19/1. 
Tefsirlerde daha çok Hızır'ın sıfatı ile ilgili mülahazalar vardır. Mesela Mâtürîdî, âyette Hızır'a verildiğinden bahsedilen rahmetin nübüvvet olmasını mümkün görmektedir. Ona göre ilgili âyette Hızır'ın "Ben bunu kendiliğimden yapmadım." dediğinin nakledilmesi de buna delil teşkil etmektedir.43 Begavî (ö. 516/1122) ise "İlim ehlinin çoğunluğuna göre Hızır peygamber değildir." demektedir.44 Râzî'nin bildirdiğine göre ise müfessirlerin çoğu, Hızır'ın peygamber olduğu kanaatindedirler. Onlar, ilgili âyette Hızır için "Ona katımızdan bir rahmet verdik." buyrulduğunu, "rahmet" kelimesinin ise Kur'ân'ın bazı âyetlerinde nübüvvet anlamında kullanıldığını" ${ }^{45}$ belirtmektedirler. Onlara göre Hızır için "Kendisine nezdimizden bir ilim öğrettik." buyrulması da onun peygamberliğine delalet etmektedir. Râzî bunlarla birlikte beyan edilen daha başka delilleri de zikrettikten sonra, bunların tam olarak Hızır'ın peygamberliğine delalet edici mahiyette olmadıklarını ifade etmektedir. Mesela Kur'ân'da geçen her rahmet kelimesinin, nübüvvet anlamında kullanılmadığını ve insandaki zarurî (fıtrî) bilgilerin de Allah'tan olduğunu ama bunların, o insanın peygamber olmasını gerektirmediğini dile getirmektedir. ${ }^{46}$

Kurtubî'ye göre ise müfessirlerin Hızır'ın nebi olduğuna yönelik görüşlerine âyet-i kerîmenin de şahitliği söz konusudur. Nitekim âyete göre Hızır, yaptıklarının iç yüzünden haber vermektedir ve bu durum, ancak vahiy ile vakıf olunabilecek bir şeydir. Yine bir insan, ancak fevkinde olan bir kimseden ilim öğrenir ve öyle birine tabi olur. Nebinin üzerinde ise nebi olmayan bir kimsenin bulunması câiz olmaz. Hızır'ın kendisine bâtın ilmi verilen bir melek olduğu da söylenmiştir ancak Hızır'ın nebi olduğu izahı doğru görünmektedir. ${ }^{47}$

Görüldüğü üzere müfessirlerin Hızır'ın vasfı ile ilgili beyanları, âyetlerden yaptıkları çıkarımlara göre değişiklik arz etmektedir. Bir müfessire göre ilgili âyetler, Hızır'ın peygamberliğine şahitlik ederken diğerine göre tam tersine buna delalet etmemektedir. Netice itibariyle anlaşılmaktadır ki "Mûsâ-Hızır kıssasında, ledünnî bilgiye sahip kişiden ziyade Allah'ın ilminin keyfiyetine ve vüsatına vurgu yapilmaktadır." 48

\section{1. 5. İki Denizin Birleştiği Yer}

Mücâhid (ö. 103/721) ve Katâde’ye (ö. 117/735) göre burası, Bizans ve İran denizidir.49 Muhammed b. Ka'b'ın (ö. 108/726 [?]) beyanına göre bu iki denizin Ürdün denizi ile Kulzum (Kızıl) denizi olduğu söylendiği gibi Tanca yakınlarındaki iki denizin birleştiği yer olduğu da söylenmiştir. Übey b. Ka'b'dan ise buranın Afrika'da olduğu nakledilmiştir. Süddî (ö. 127/745) de bu iki denizin el-Kurr ve er-Ress

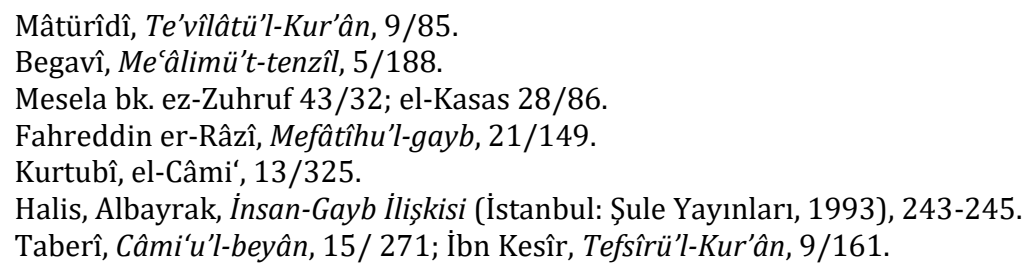


denilen nehirler olduğunu, bunların da Ermenistan'da bulunduklarını ifade etmiştir. İbn Atiyye (ö. 541/1147) ise buranın “Azerbaycan'ın arka taraflarında bulunan, Fars (İran) topraklarındaki büyük denizden ayrılan ve kuzeyden güneye doğru akan bir kol olduğu" şeklinde bir görüş beyan etmiştir. Buna göre Şam bölgesinin karasına yakın yerde olan iki denizin bir araya geldiği yer, bu iki denizin kavuştuğu yer olmalıdır. Bazı ilim adamları ise buranın, Endülüs'ün kıyılarının bulunduğu okyanus olduğunu beyan etmişlerdir. 50

Râzî, bu yerin tespiti ile ilgili sadece "Burası, Fars deniziyle Rum denizinin doğu yakasından birleştikleri yerdir veya daha başka bir yer olduğu da söylenmektedir." demektedir. 0, âyete göre bu iki denizi tayin edip belirtecek herhangi bir delâletin bulunmadığını da belirterek sahih haberle doğru olarak ortaya konulan bir şey olmadığı zaman susmanın daha evla olduğunu ifade etmektedir. ${ }^{51}$ İki denizden kasıt Mûsâ ile Hızır'dır, diyenler de olmuştur. Râzî bu izahı, "Çünkü onlar da adeta iki ilim denizidirler." yorumuyla vermiş,52 Kurtubî ise bu izahın, İbn Abbas'tan nakledilmiş olsa da zaylf olduğunu beyan ederek hadislerden buradaki denizin suların bulunduğu bir deniz olduğunun anlaşıldığını söylemiştir. 53

Yukarıda da görüldüğü üzere mecmau'l-bahreyn hakkında müfessirlerin muhtelif izahları olmuştur. Râzî̀nin de belirttiği gibi bu konu, sahih haberle izah edilmediğine göre onun hakkında konuşmamak daha iyidir. Zira bu yeri bilmenin herhangi bir faydası yoktur ki orayı, yüce Allah da açıklamamıştır.

\section{2. Hz. Mûsâ'nın Hızır ile İlim Öğrenmek İçin Sözleşmesi}

Kıssanın ikinci aşamasından bahseden Kehf sûresinin 66-70. âyetlerinde, Hz. Mûsâ'nın Hızır ile sözleşmesi söz konusu edilmektedir. Buna göre Hz. Mûsâ, kendisine öğretilenden öğretmesi için Hızır'a tâbi olmak istemiş, Hızır da bu bilgiyi öğrenme konusunda kendisine sabredemeyeceğini bildirmiştir. Neticede Hz. Mûsâ'nın ısrarıyla "hiçbir şey hakkında soru sormama” koşuluyla anlaşmışlardır.

Klasik tefsirler ekseriyetle kıssayı bir kelamcı ve fikıhçı bakış anlayışıyla daha genel bir ifadeyle beyanî te'vil yöntemiyle yorumlamışlardır ki bu husus tefsir literatürüne hâkim paradigmanın adresini de vermiş olmaktadır. Eğer Hızır velî ise Hz. Mûsâ gibi ülü'l-azm bir peygamberin kendisinden manen aşağıda olan bir veliye ittibâ etmesi nasıl izah edilebilir? Eğer nebi ise aynı anda iki şeriata sahip nebiden hangisi metbû hangisi tabi konumundadır? Tefsirlerde, öncelikle bu sorulara

\footnotetext{
50 Ebû Muhammed Abdülhak b. Gâlib b. Abdirrahmân el-Endelüsî İbn Atıyye, el-Muharrerü'l-vecîZ fí tefsîri'l-kitâbi'l-'azîz, thk. Abdüsselâm Abdüşşâfî Muhammed (Beyrut: Dâru'l-Kütübi'l-'Ilmiyye, 1422/2001), 3/527; Kurtubî, el-Câmi', 13/325.

Fahreddin er-Râzî, Mefâtîhu'l-gayb, 21/146.

Fahreddin er-Râzî, Mefâtîhu'l-gayb, 21/147.

Kurtubî, el-Câmi', 13/315-316.
} 
cevaplar aranıp izahlar getirilmektedir.54 "İstitâat maa'l-fiil midir yoksa kable'l-fiil midir?" sorusu da kıssa ile ilgili dile getirilen sorular arasında yer almaktadır. ${ }^{55}$

\section{2. 1. İlim Öğrenmeyi İstemenin Gerekliliği ve Edepleri}

Hz. Mûsâ, kendisine Tevrat verilen ve büyük peygamberlerden olan bir zattır. Onun bu haliyle ilim talep edip yolculuğa çıkması, özellikle şuna işaret etmektedir: Hiçbir kimseye, o ilmin nihayetine erişse ve zamanının bütün ilimlerine vakıf olsa bile, ilim talebini terk etmesi ve kendisinden daha bilgili bir kimseye karşı tevazu göstermemesi layık değildir. ${ }^{56}$ Âyet-i kerîmede ilk önce Hz. Mûsâ'nın Hızır'a "Sana tabi olayım mı?" demesi zikredilmiştir ki burada son derece güzel bir edep üslubu ve latif bir isteme örneği sunulmaktadır. ${ }^{57} \mathrm{Bu}$ ifadeden "ilim öğrenen kimsenin, ilim öğrendiği zata tabi olması gerektiği de anlaşılmaktadır. ${ }^{58}$ Kurtubî de ilgili beyanın, fazilet yönünden mertebeleri farklı da olsa ilim tâlibinin âlime tabi olmasının gerekliliğine işaret ettiğini ifade etmektedir. ${ }^{59}$

Râzî ise Hz. Mûsâ'nın Hızır'dan ilim öğrenmek isterken pek çok edep ve inceliğe riayet ettiğini belirtmektedir. Bunlar da şu şekilde sıralanabilir: İttibâ edeceğini bildirmek, izin istemek, kendine cehaleti üstada ilmi nispet etmek, üstaddan Allah'ın kendisine öğrettiği şeylerin bir kısmını öğretmesini istemek, hocaya ilmi verenin Allah olduğu bilincinde olmak, hocadan hidayete sevk eden ilmi talep etmek, Allah'ın hocaya yaptığı muamele gibi onun da kendisine muamelede bulunmasını istemek, hocaya bütün işlerinde tabi olmayı istemek, tabi oluşundan dolayı ilimden başka bir şey istememek.60 Yine Râzîye göre ilgili beyanlarda Hz. Mûsâ'nın Hızır'a "Allah dilerse beni sabırlı bulacaksın. Sana hiçbir işte karşı gelmeyeceğim." demesi de yoğun bir tevazuu, bir tahammül ve alçak gönüllülüğü ortaya koymaktır ki bütün bunlar, öğrenimde bulunan kimsenin, kusursuz bir tevazu sergilemesi gerektiğini göstermektedir.61

\section{2. 2. Hz. Mûsâ'nın Hızır'dan Öğrenmek İstediği İlmin Mahiyeti}

Taberî̀nin beyanına göre Hz. Mûsâ'nın Hızır'dan öğrenmek istediği ilim, Hakk'a irşat eden ve hidayete delil olan bir ilimdir ki bu ilmi Allah öğretmiştir. Hızır, ilm-i bâtın olan bu ilimle amel etmektedir. ${ }^{62}$ Mâtürîdî de burada bahsedilen ilmin rüşd ve doğruluğun ilmi olduğunu vurgulamaktadır. ${ }^{63}$ Begavî ise onun, ilham yoluyla

\footnotetext{
Begavî, Me âlimü't-tenzîl, 5/187; Zemahşerî, el-Keşşâf, 625; Fahreddin er-Râzî, Mefâtîhu'l-gayb, 21/149-151.

55 Mâtürîdî, Te'vîlâtü'l-Kur'ân, 9/89; Fahreddin er-Râzî, Mefâtîhu'l-gayb, 21/153.

56 Zeccâc, Meâni'l-Kur'ân, 3/301; Ebû Ca'fer Ahmed b. Muhammed en-Nehhâs, Me'âni'l-Kur'âni'lkerîm, thk. Muhammed Ali es-Sâbûnî (Mekke: Merkezü İhyâi't-Türâsi'l-İslâmî, 1408-1410/19881989), 4/267.

Nehhâs, Meâni'l-Kur'ân, 4/267.

Mâtürîdî, Te'vîlâtü'l-Kur'ân, 9/86.

Kurtubî, el-Câmi', 13/326.

Fahreddin er-Râzî, Mefâtîhu'l-gayb, 21/152.

Fahreddin er-Râzî, Mefâtîhu'l-gayb, 21/154.

Taberî, Câmi'u'l-beyân, 15/ 283.

Mâtürîdî, Te'vîlâtü'l-Kur'ân, 9/87.
} 
elde edilen türde bir ilm-i bâtın olduğunu söylemektedir.64 İbn Atıyye'nin bildirdiğine göre Hızır'ın bilgisi, kendisine vahiy ile verilmiş olup işlerin içyüzlerini bilme ilmidir. Hızır'a zâhirî hükümler verilmemiştir ve fiilleri de buna göredir. Hz. Mûsâ'nın bilgisi ise insanların söz ve fiillerinin zâhirine göre hüküm ve fetva verme ilmidir.65 Zemahşerî bu ilmin "gaybden haber verme" olduğunu beyan ederken ${ }^{66}$ İbnü'l-Cevzî (ö. 597/1201) onu, İbn Abbas'ın "gayb ilminden bir miktar ilim" olarak izah ettiğini belirtmektedir.67 İbn Kesîr ise bu ilmin "faydalı ve salih amele sevk eden bir ilim" olduğunu ifade etmektedir.68

\section{2. 3. İnsanda İstitâatın Ne Zaman Bulunduğu}

Kehf sûresinin 67. âyetinde anlatıldığına göre Hızır, Hz. Mûsâ'ya "kendisiyle birlikte olmaya güç yetiremeyeceğini" söylemektedir. Sûrenin 72 . âyetinde ise Hızır'ın "Benimle beraberliğe sabredemezsin, demedim mi?" dediği nakledilmektedir. $\mathrm{Bu}$ âyetlerde güç yetirme eylemi, istitâat kelimesiyle ifade edilmiştir ki bununla ilgili olarak tefsirlerde, bu eylemin kulda ne zaman bulunduğu konusunun gündeme getirildiği görülmektedir. İstitâat, sözlükte "muktedir olmak, gücü yetmek" anlamlarına gelir. Terim olarak ise "kendisiyle bir fiili yerine getirmeyi mümkün kılacak bir gücün var olması" demektir.69

Mâtürîdî ilgili beyanın, kişinin fiile mukarin olan ve fiilin kendisiyle gerçekleștiği bir istitâata muhtaç olduğuna delalet ettiğini, söylemektedir. Yani istitâat, Mû‘tezile'nin söylediğinin aksine fiilden önce değil fille birlikte var olmaktadır.70 Râzî de tefsir âlimlerinin âyet-i kerîmedeki "Doğrusu sen, benim yanımda asla sabredemezsin!" ifadesinden fiilden önce istitâatın bulunamayacağını çıkarttıklarını belirtmektedir. Onlara göre herhangi bir fiile muktedir olma işi, fiilden önce mevcut olsaydı, sabra güç yetirebilme de sabır fiilen tahakkuk etmeden önce Hz. Mûsâ'da bulunmuş olurdu. Bu durumda ise âyette geçen "Doğrusu sen, benim yanımda asla sabredemezsin!” ifadesi, yalana dönüşürdü. Bu böyle olamayacağına göre fiilden önce istitâatın bulunamayacağı anlaşılmaktadır. Râzî̀ye göre tefsir âlimlerinin yapmış olduğu istidlali, 68. âyette geçen "Kavrayamadığın bir bilgiye nasıl sabredeceksin?" ifadesi de desteklemektedir. Çünkü bu ifade, insanın bir şeyin hakikatine vakıf olmadan ona sabretmesinin mümkün olmadığını anlatmaktadır. Buna göre de fiilden önce istitâatın olamayacağı anlaşılmış olmaktadır.71

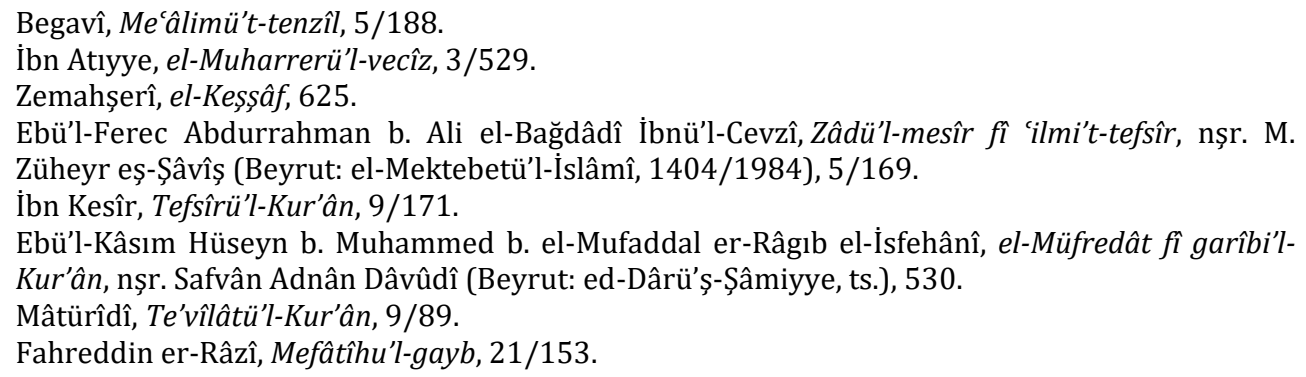




\section{2. 4. Hızır'ın Soru Sorulmamasını İstemesi}

Kehf sûresinin 70. âyetine göre Hızır, Hz. Mûsâ'dan "herhangi bir konuda kendisi açıklama yapmadıkça soru sormamasını" istemektedir. Zeccâc, bu ifadenin "Bir işi münker görürsen onun izahını ben sana yapmadıkça soru sorma!" anlamına geldiğini,72 Mâtürîdî ise onun, "Nefsinin hoş görmediği ve ikrah ettiği bir şey hakkında ben sana, yaptığımı niçin yaptığımı anlatmadıkça soru sorma!" demek olduğunu ifade etmektedir. ${ }^{73}$ Semerkandî (ö. 373/983) de ilgili beyanın "Münker gördüğün bir şey olursa onu bana sorma konusunda acele etme!" anlamına geldiğini belirtmektedir. ${ }^{74}$ Râzîye göre ise bu söz, "Benden sadır olduğunu gördüğün ve manasını bilmediğin şeylere dair, bana bir şey sorma! Ta ki ben onları sana öğretmek ve haber vermek üzere girişimde bulunayım." demektir. ${ }^{75}$

Tefsirde daha çok beyanî yöntemi kullanan müfessirlerin de ifade ettiği üzere ortada, en azından görüntü itibariyle, münker olacak bir durum vardır ve Hızır, bu konuyla ilgili soru sorulmamasını istemektedir. Beyan ehli müfessirler, genel ifadelerle ilgili sözün ne demek olduğunu belirtmişler fakat "soru sormamanın" niçin istendiği üzerinde pek durmamışlardır. Az da olsa onlardan bazılarının ise bu hususu, talim ve teallümün edebi olmakla ilişkilendirdikleri müşahede edilmektedir. Mesela Zemahşerî'nin bu durumu, öğrencinin âlime karşı göstermesi gereken edeplerden olarak izah ettiği,76 Kurtubî”nin ise "Hızır'ın Hz. Mûsâ'ya edep öğretiminde bulunması ve arkadaşlıklarının devamını gerektiren konulara irşadı" olarak değerlendirdiği görülmektedir. ${ }^{77}$ İrfanî yapının temsilcisi olan müfessirlerin ise bu konuyu direk olarak âlime karşı öğrenci tarafından gösterilmesi gereken edeplerden saymak suretiyle izah ettikleri görülmektedir. ${ }^{78}$

Buraya kadar bahsedilenlerden anlaşıldığı üzere Hz. Mûsâ ile Hızır, yolculuğa çıkmadan önce bir sözleșme konuşması yapmışlardır. Kıssada, buradan itibaren Hz. Mûsâ ile Hızır yolculuğu başlamış bulunmaktadır.

\section{3. Gemi Yolculuğu}

Hz. Mûsâ ile Hızır yolculuğunun ilk aşaması, onların gemide yaptıkları yolculuktur. Kehf sûresinin 71-73. âyetlerinde anlatıldığına göre onlar, gemiye bindikleri zaman Hızır gemiyi delmiş Hz. Mûsâ da buna itiraz etmiştir. Buna karşılık Hızır, önceden Hz. Mûsâ'ya "kendisiyle beraberliğe sabredemeyeceğini" belirttiğini hatırlatmış; Hz. Mûsâ ise "unuttuğu șeyden dolayı kendisinin muaheze

Zeccâc, Me'âni'l-Kur'ân ve i'râbüh, 3/301.

Mâtürîdî, Te'vîlâtü'l-Kur'ân, 9/87.

Semerkandî, Tefsîru's-Semerkandî, 2/306.

Fahreddin er-Râzî, Mefâtîhu'l-gayb, 21/154.

Zemahșerî, el-Keșşâf, 625.

Kurtubî, el-Câmi', 13/327.

Rûzbihân b. Ebî Nasr el-Baklî, 'Arâ'isü'l-beyân fî hakâ'ikı'l-Kur'ân, thk. Ahmed Ferîd el-Mezîdî (Beyrut: Dâru'l-Kütübi'l-'Ilmiyye, 1429/2008), 2/432; et-Te'vîlâtü'n-Necmiyye, 4/146-147; Bursevî, Rûhu'l-beyân, 5/277; Şehâbeddîn Mahmûd el-Âlûsî, Rûhu'l-mecânî fî tefsîri'l-Kur'âni'l'azîm ve's-seb 'i'l-mesânî (Beyrut: Dâru İhyâi't-Türâsi'l-Arabî, ts.), 15/335. 
edilmemesini" isteyerek özür beyanında bulunmuştur. ${ }^{79}$ Tefsirlerde kıssanın bu bölümüyle ilgili merkeze alınan hususlar şu șekildedir:

\section{3. 1. Hızır'ın Gemiyi Delmesi}

Hızır'ın gemiyi delmesi, Hz. Mûsâ ile Hızır yolculuğunun ilk şaşılacak olayıdır. $\mathrm{Bu}$ yönüyle de müfessirlerin konuyla ilgili muhtemel sorulara cevap verme çabaları olmuştur. Mesela "Hızır, nasıl oluyor da herkesin gözü önünde gemiyi deliyor?" sorusu akıllara gelebilir. Muhtemelen böyle bir soruya cevap olmak üzere "Hızır gemiyi deldiği zaman onu, Mûsâ'dan başka kimse görmedi. Çünkü Hızır ancak yüce Allah'ın göstermeyi dilediği kimsenin gözüyle görülebilen bir kimseydi. Eğer gemidekiler onu görmüş olsalardı, gemiyi delmesini engellerlerdi." yorumu yapılmış, "Gemi sahipleri bir adaya çıkmışlar, geride Hızır kalmış ve gemiyi o vakit delmişti." de denilmiştir. 80

Tefsirlerde, "Hızır, gemiyi delince neler oldu?" sorusunun da cevaplanmaya çalışıldığı görülmektedir. Mesela "Hızır gemiyi delince ona suyun girmediği", “(Hızır’ın gemiyi deldiğini) gören Hz. Mûsâ'nın elbisesini alarak deliği tıkamaya çalıştığı", "Hızır'ın bir cam parçası alarak geminin deliğini yamadığı" gibi yorumlar dile getirilmiştir. ${ }^{81}$ İbn Abbas'ın ise konuyla ilgili başka bir açıyı şu şekilde ifade ettiği nakledilmektedir: "Hızır gemiyi deldiğinde Mûsâ bir kenara çekildi ve kendi kendine 'Ben bu adamın arkadaşlığını ne yapayım? İsrailoğulları arasında sabahakşam Allah'ın Kitabını okuyordum, onlar da bana itaat ediyorlardı.' dedi. Hızır ona, 'Ey Mûsâ! İçinden neyi geçirdiğini sana haber vermemi ister misin?' dedi. 0, 'Evet!' deyince, Hızır 'Şunları içinden geçirdin.' dedi. Mûsâ da 'Doğru söyledin!' diye cevap verdi." 82

Yukarıda nakledilen izahların bazılarında, “Hızır'ın herkes tarafından görülmediği" ve "Hızır'ın Hz. Mûsâ'nın içinden geçenleri bildiği” gibi normal şartlar altındaki bir kimsede bulunmayan bir takım özelliklerin Hızır’a nispet edildiği görülmektedir. Tefsirlerde yer alan bu tür izahların, Hızır'ın olağan dışı pozisyonunu ortaya koyduğu görülmektedir.

\section{3. 2. Hz. Mûsâ'nın İtirazı ve Özür Beyanı}

İlgili âyette gemiyi delen Hızır'a karşılık Hz. Mûsâ'nın “İçindekileri boğmak için mi onu deldin?" dediği rivayet edilmektedir. Bu beyanın iki şekilde anlaşılabileceğini ifade eden Mâtürîdî; ilk olarak onun inkâr etme/karşı çıkma, ikinci olarak ise soru sorma/nedenini araştırma manasına gelebileceğini belirtmektedir. $\mathrm{Bu}$ durumda birinci tevcihe göre Hz. Mûsâ, peygamberlerin âdeti olduğu üzere görünüş itibariyle münker bir fiil görünce ona karşı çıkmıştır. İkinci tevcihe göre ise Hz. Mûsâ, "İçindekileri boğmak için mi veya başka bir sebepten mi onu deldin?" diye

el-Kehf 18/71-73.

Kurtubî, el-Câmi', 13/328

Begavî, Me âlimü't-tenzîl, 5/190; Bursevî, Rûhu'l-beyân, 5/278.

Kurtubî, el-Câmi', 13/328. 
soru sormuştur ki bu durumda Hz. Mûsâ'nın “Gerçekten sen çok kötü bir iş yaptın!” şeklindeki beyanı, "Eğer bunu içindekileri boğmak için yaptınsa, çok kötü bir iş yaptın!" takdirindedir. 83

Yine âyette ifade edildiğine göre Hz. Mûsâ'nın itirazı sonrasında Hızır ona "Benimle beraberliğe sabredemezsin!" dediğini hatırlatmakta, Hz. Mûsâ ise "Unuttuğum şeyden dolayı beni sorumlu tutma!" diyerek özür beyanında bulunmaktadır. ${ }^{84}$ Müfessirler, bu beyandaki nisyan kelimesi üzerinde durmuşlar, onun "gaflet etmek, hatırlamamak, unutmak", "unutur gibi olmak" veya "terk etmek" anlamlarına gelebileceğini beyan etmişlerdir.85 "Nisyanın 'unutmak' anlamına alınması durumunda ise bu âyet, 'Unutana, sorumluluğun olmayacağı' hususuna delil

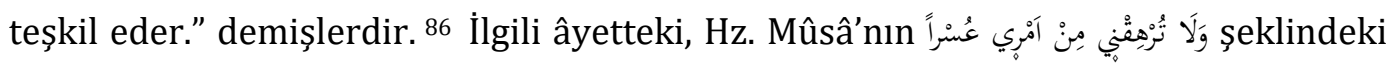
beyanı ise "Bana zor gelen bir işten dolayı beni sorumlu tutma" veya "Bana zor gelen şeyi yükleme" ya da "Beni zora sokma" diye anlaşılmıştır. ${ }^{87}$

\section{4. Bir Gulâm ile Karşılaşmaları}

Hz. Mûsâ ile Hızır yolculuğunun ikinci aşaması, bir erkek çocukla ilgili olarak gelişme göstermektedir. Kehf sûresinde anlatıldığına göre Hz. Mûsâ ile Hızır yolculuklarının devamında bir erkek çocukla karşılaşmışlar, Hızır hemen o çocuğu öldürmüş, Hz Mûsâ da buna itirazda bulunmuştur. Buna karşılık Hızır tekrar Hz. Mûsâ'ya "kendisiyle beraberliğe sabredemeyeceğini" önceden söylediğini hatırlatmış, Hz. Mûsâ ise "bundan sonra bir şey sorarsa kendisine arkadaşlık etmeme konusunda Hızır'ın mazur olacağını" ifade etmiştir. 88 Tefsirlerde bu konu ile ilgili cevap aranan bazı sorular şunlardır: Öldürülen oğlan sabî mi, ergen bir delikanlı mı? Kâfir mi, mümin mi? Günahkâr mı, suçsuz mu? Hz. Mûsâ'nın sözleri ne ifade etmektedir?89

\section{4. 1. Öldürülen Gulâmın Durumu}

Hz. Mûsâ ile Hızır'ın yolculukları sırasında karşılaştıkları ve neticede Hızır tarafından öldürülen kimse, âyet-i kerîmede "gulâm" olarak geçmektedir ki sözlükte, bu kelimenin "yeni doğan erkek çocuk için kullanıldığı ve orta yaşlı kimse için de 'gulâm necîb' șeklinde bir tabir olduğu" ifade edilmektedir..$^{90} \mathrm{Bu}$ doğrultuda müfessirlerin de öldürülen bu kimsenin bâliğ olup olmadığı konusunda ihtilaf ettikleri görülmektedir.

Mâtürîdî, Te'vîlâtü'l-Kur'ân, 9/88.

el-Kehf 18/72-73.

Mâverdî, en-Nüket ve'l- 'uyûn, 3/327.

Fahreddin er-Râzî, Mefâtîhu'l-gayb, 21/155; Kurtubî, el-Câmi', 13/329.

Mâtürîdî, Te'vîlâtü'l-Kur'ân, 9/90.

el-Kehf 18/74-76.

Mâtürîdî, Te'vîlâtü'l-Kur'ân, 9/93-94; Taberî, Câmi'u'l-beyân, 15/286.

Muhammed b. Ahmed el-Ezherî, Tehzîbü'l-luga, thk. Muhammed Ali en-Neccâr vd. (Beyrut: edDârü'l-Mısriyye, 1383/1964), "glm”, 8/141. 
İbn Abbas'tan gelen bir rivayete göre âyette geçen gulâm, kâfir olup yol kesen ve henüz deşifre edilmemiş bir adamdı. Saîd b. Cübeyr'in (ö. 94/713 [?]) İbn Abbas'tan naklettiğine göre ise 0 , bâliğ olmamış bir çocuktu. ${ }^{91}$ Mâverdî (ö. 450/1058) de öldürülen gulâmın bâliğ olup olmadığı konusunda ihtilaf edildiğini ifade ettikten sonra İbn Abbas'ın bu konuyla ilgili olarak "Genç bir adamdı; bâliğ değildi ve onun hakkında kalem, öldürülmeyi hak edecek bir şey yazmamıştı." dediğini nakletmekte ve Arapça'da bazen adam (racül) için gulâm kelimesinin kullanıldığını ifade etmektedir. Bununla birlikte çoğu müfessirin onun, "bâliğ olmayan küçük bir çocuk olduğu" görüşünde olduklarını da belirtmektedir. ${ }^{92}$

Begavî'nin naklettiğine göre gulâm hakkında İbn Abbas, “Günah işleme çağına ulaşmamıştı.", Dehhâk (ö. 105/723) "Fesat işleyen ve anne babasının kendisinden eziyet gördüğü biriydi.", Hasan-ı Basrî (ö. 110/728) "Racül (adam) idi." ve Kelbî (ö. 146/763) "Yol keserek haraç toplayıp anne babasına sığınan bir gençti." demişlerdir. Begavî, konuyla ilgili son olarak Hz. Peygamber'in (s.a.s.) "Hızır'ın öldürdüğü çocuk kâfir olarak (takdir edilip) yaratılmıştı. Yaşasaydı annesine, babasına azgınlı ve küfürle zulmederdi." 93 buyurduğunu nakletmekte ve müfessirlerin izahlarına yönelik herhangi bir tercihte bulunmamaktadır. ${ }^{94}$

Dikkat edilirse gulâm ile ilgili nakledilen bazı izahlar, onun öldürmesini meşru kılacak bilgiler mahiyetindedir. Bununla birlikte onun öldürülmesinin $\mathrm{Hz}$. Mûsâ tarafından fena bir şey olarak ifade edilmesi, Hızır'ın yaptıklarının meşruluğunu tartışmaya açmaktadır. Buna karşılık da müfessirlerin cevap arayışına girdikleri, "büluğa ermemiş bir çocuğun cezalandırılmasının Hızır’ın şeriatına göre câiz olabileceği" gibi çözümler ürettikleri görülmektedir. ${ }^{95}$

\section{4. 2. Hz. Mûsâ'nın İtirazı}

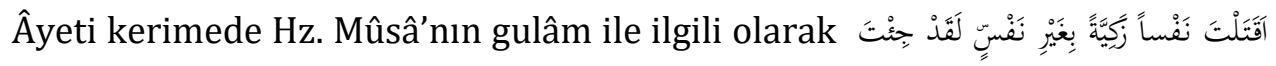

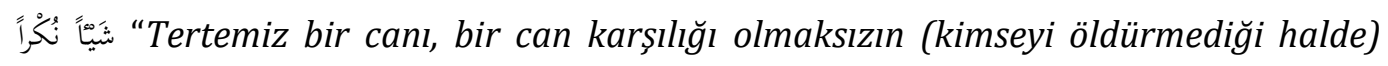
katlettin ha! Gerçekten sen fena bir şey yaptın!"96 dediği nakledilmektedir ki Mâtürîdî bu beyanın inkâr etme ve karşı çıkma, ya da soru sorma/sebebini araştırma manalarında olabileceğini belirtmektedir. Birinci yoruma göre Hz. Mûsâ'nın كََْْ حِنْتَ شَيًْا نُكْرَاً ifadesi, “Gerçekten sen münker bir şey yaptın!” anlamına gelmektedir. Müfessirler, bu sözdeki نُخْرَ kelimesi üzerinde de durmuşlar ve Hz. Mûsâ'nın Hızır'a bir önceki itirazında إمْراً kelimesini kullanmasıyla bunu, kıyaslama yoluna

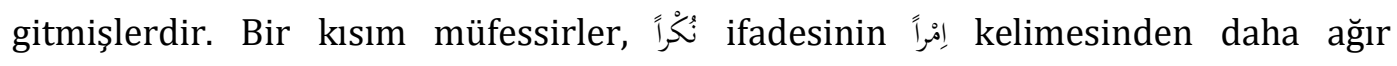

Semerkandî, Tefsîru's-Semerkandî, 2/307.

Mâverdî, en-Nüket ve'l-'uyûn, 3/328.

Müslim, "Kader", 6.

Begavî, Me âlimü't-tenzîl, 5/191.

Âlûsî, Rûhu'l-me ânî, 16/17.

el-Kehf 18/74. 
olduğunu, çünkü can karşılığı olmaksızın bizzat adam öldürmenin ve cana kıymanın daha büyük bir şey ifade ettiğini beyan etmişlerdir. Müfessirlerin bazıları ise tam tersi görüş beyan ederek إِمْراً ifadesinin, نُكُرًاً kelimesinden daha büyük olduğunu söylemişlerdir. Çünkü gemiyi delmede bir topluluğun helaki, gulâmın öldürülmesinde ise bir canın telef edilmesi söz konusu olmaktadır. ${ }^{97}$

Hz. Mûsâ'nın sözünde gulâm hakkında şeklinde bir beyanın bulunması da müfessirlerin dikkatini çeken bir konudur. Bu hususta onların

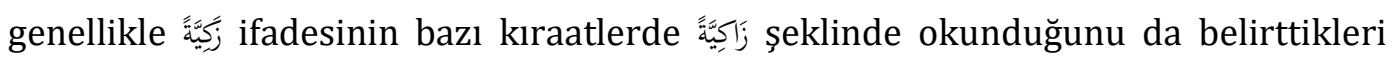
görülmektedir. Müfessirlerin çoğu, bu iki kelimenin aynı manaya geldiği görüşündedirler. Onlar, bu doğrultuda her iki kelimeye "tövbekâr, temiz, artmış, Müslüman, kanı helal olmayan, hata işlememiş" anlamları vermişlerdir. Bu iki kelime arasında mana farkı olduğu görüşünde olan müfessirler ise şu izahları yapmışlardır:

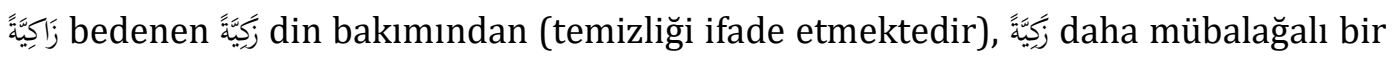

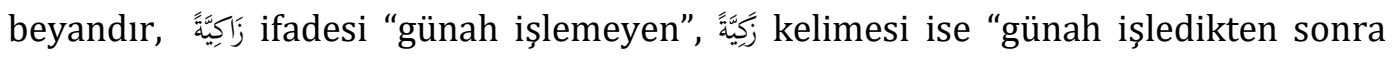
tövbe eden ve bağışlanan" manasına gelmektedir. ${ }^{99}$

Görüldüğü üzere tefsirlerde ilgili âyetlerde geçen en küçük ayrıntı bile değerlendirilmiş; kelime farklılıkları, kıraat farkları ve bunların manaya yansıması üzerinde detaylı bir şekilde durulmuştur.

\section{5. Hızır'ın Yıkılmak Üzere Olan Duvarı İmarı}

Hz. Mûsâ ile Hızır, yolculuklarının üçüncü aşamasında bir köye uğramışlardır. Kehf sûresinin 77-78. âyetlerinde anlatıldığına göre onlar, köy halkına varıp onlardan yiyecek istemişler, köylüler ise onları misafir etmekten kaçınmışlardır. Bu duruma rağmen Hızır, köyde yıkılmak üzere bulunan bir duvarı tamir etmiş, Hz. Mûsâ da "Dileseydin, buna karşı bir ücret alırdın." diye itirazda bulunmuştur. Bunun neticesinde Hızır, Hz. Mûsâ'ya "bunun aralarının ayrılması demek olduğunu" belirtmiş ve ona "sabredemediği şeylerin içyüzünü haber vereceğini" söylemiștir. ${ }^{100}$

Tefsirlerde kıssanın bu bölümü ile ilgili olarak bazı konulara temas edildiği ve hatta çeşitli hükümlere varıldığı görülmektedir. Mesela yiyecek istemenin câiziyyeti, Kur'ân'da mecâzın varlığı ve velilerin kerametlerinin olduğu meseleleri bu âyetlerden çıkarılan hükümlerdendir.

\section{5. 1. Yiyecek İstemenin Durumu}

Müfessirlerden bazıları söz konusu âyetin, "yiyecek istemenin hükmü" ile ilgili mesajlar içerdiği görüşündedirler. Mesela Râzî, "Yemek istemek, kerim

Mâtürîdî, Te’vîlâtü'l-Kur'ân, 9/89-90.

el-Kehf $18 / 74$.

Mâverdî, en-Nüket ve'l-'uyûn, 3/330; Begavî, Me âlimü't-tenzîl, 5/191.

100 el-Kehf 18/77-78. 
kimselerin âdetlerinden değildir. Hz. Mûsâ ve o âlim bunu nasıl yapabilmişlerdir?" şeklinde bir soru sorarak konuya girmiş ve ardından şu cevabı vermiştir: "Aç kimsenin yemek istemesi, bütün şeriatlarda mubah olan bir iştir. Hatta bazen, açlıktan dolayı büyük bir zarar meydana geleceği hissedildiğinde, bunu yapmak vacip olur."101 Kurtubî de ilgili âyetin bazı cahil mutasavvıfların görüşlerinin hilafına "yiyecek istenebileceğine ve acıkan kimsenin açlığını giderecek miktardaki şeyleri istemesinin vacip olduğuna" delil teşkil ettiği kanaatindedir. Ona göre âyette geçen استطعام/istit'âm, yemek yedirilmeyi istemek demektir. Buna göre ilgili âyette kastedilen mana, kendilerinin misafir edilmesini istemektir. Hızır ve Mûsâ (a.s.), kendileri için hak olanı istemişlerdir. ${ }^{102}$

\section{5. 2. Hızır'ın Duvarı Düzeltmesinin Anlamı}

Kehf sûresinin 77. âyetinde, Hızır'ın yıkılmaya yüz tutmuş duvarı doğrultmasından bahsedilmektedir ki bunun ne demek olduğu ile ilgili de farklı izahların yapıldığı görülmektedir. Bu ifade müfessirlere göre " 0 , onu yıktı; sonra yaptı." ya da "O, onu eliyle düzeltti." anlamlarına gelmektedir. "O, ona elini sürdü de bunun üzerine o dosdoğru oldu, düzeliverdi." demek olduğu da söylenmiştir ki Râzî’ye göre bu durum, Hızır'ın mucizelerindendir. ${ }^{103}$ Kurtubî de konuyla ilgili Saîd b. Cübeyr'in "Onu eliyle sıvazladı ve doğrulttu, o da dosdoğru oluverdi." dediğini nakletmekte ve bu olayın peygamberlerin mucizelerine, hatta evliyanın kerametlerine benzediğini beyan etmektedir. Ayrıca bunun, velilerin kerametleri olduğuna delil teșkil ettiğini de ifade etmektedir. ${ }^{104}$ Görüldüğü üzere müfessirlerin burada, Hızır'ın yıkılmaya yüz tutmuş duvarı çabucak tamir etmesini, olağanüstü bir faaliyet olarak aktarmaları söz konusu olmuştur. Bu durumun mucize veya keramet olarak yorumlanması da onlar tarafından Hızır'ın peygamber veya veli olarak kabul edilmesine göre değişmektedir.

Duvarın yüksekliğinin beş yüz zirâ, uzunluğunun iki yüz zirâ, genişliğinin kırk zirâ olduğu; altında halka ait bir yol bulunduğu gibi bazı rivayetlerin varlığına değinen Mâtürîdî, diğer İsrailî rivayetlerde olduğu gibi "bunları bilmeye ihtiyacımızın olmadığını, kıssadaki hikmet ve faydaları bilmeye muhtaç olduğumuzu" vurgulamaktadır.105 Ayrıca birçok müfessire göre âyet-i kerîmede duvara, “يُريديد/irade eder” kelimesinin izafe edilmesi, Kur'ân'da mecâzın varlığına delil teşkil etmektedir.106

Fahreddin er-Râzî, Mefâtîhu'l-gayb, 21/159.

Kurtubî, el-Câmi', 13/335.

Fahreddin er-Râzî, Mefâtîhu'l-gayb, 21/158.

Kurtubî, el-Câmi', 13/340.

Mâtürîdî, Te'vîlâtü'l-Kur'ân, 9/92.

Mâtürîdî, Te'vîlâtü'l-Kur'ân, 9/91-92; Nehhâs, Meâni'l-Kur'ân, 4/273; Begavî, Me'âlimü't-tenzîl, 5/191; Zemahşerî, el-Keşşâff, 626-627; İbnü'l-Cevzî, Zâdü'l-mesîr, 5/176; Fahreddin er-Râzî, Mefâtîhu'l-gayb, 21/158; Kurtubî, el-Câmi', 13/336. 
447 | Klasik Tefsir Hareketlerinin Mûsâ-Hızır Kıssası Bağlamında Mukayesesi

\section{5. 3. Hz. Mûsâ ile Hızır'ın Ayrılık Konuşması}

Hz. Mûsâ'nın Hızır'a "Dileseydin, elbet buna karşı bir ücret alırdın." demesi üzerine o âlim kimse, "İşte bu, benimle senin aramızın ayrılmasıdır." diyerek ayrılma vaktinin geldiğini haber vermiştir. ${ }^{107} \mathrm{Bu}$ bölümle ilgili de tefsirlerde sorular sorulmuş ve cevaplar verilmiştir. Bunlardan bazıları şöyledir: Âyetteki "bu/ lafzıyla neye işaret edilmiştir? Hızır'ın sözü ne ifade etmektedir? Bu sorulara verilen cevaplar ise şöyledir: Âyetteki "bu/هذَا" lafzı, üzerinde anlaşma yapılmış olan ayrılmaya veya (sorulan) üçüncü soruya işaret etmektedir. Yani, "Bu itiraz, bizim ayrılığımızın sebebidir." demektir. Hızır’ın "İște bu, benimle senin ayrılışıdır." demesi ise "Bu aramızın ayrılığı, yani aramızdaki münasebetlerin sona ermesidir." demektir. Çünkü bazı Arap dili âlimlerine göre "beyn" kelimesi, ittisal ve münasebet anlamlarına gelmektedir.108 Konuyla ilgili İbn Abbas'tan şöyle bir izah da nakledilmektedir: Mûsâ'nın (a.s.) gemi ve gulâm hakkındaki sözleri Allah içindi (bu sebeple de ayrılmalarına sebep olmadı), duvar hakkında kendisi için dünyalık bir şey isteme babında olan sözü ise ayrılı̆̆a sebep oldu. ${ }^{109}$

Kehf sûresinin 78. âyeti, Hızır’ın Hz. Mûsâ'ya yaşanan olaylarla ilgili bazı

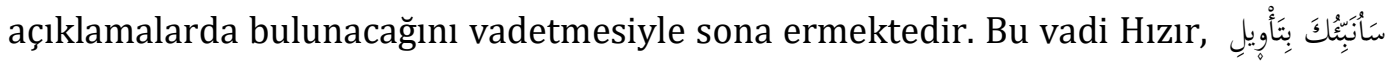
sözüyle yapmaktadır ki müfessirler bu cümlede geçen te'vil kelimesi üzerinde durmuşlar ve onun ne anlama geldiğini açılklamaya çalışmışlardır. Te'vil, müfessirlere göre "akıbet"110, "akıbet, son, sonuç"111, "beyan, açıklama"112, "tefsir"113, "hikmet"114, "meâl, işlerin yapılma sebebi"115, "haber-i bâtın"116 anlamlarına gelmektedir. Bu kelime, Türkçe çevirilerde de genellikle "içyüzü" olarak ifade edilmektedir. ${ }^{117}$ Kıssada ilgili âyetten itibaren yaşanan olayların te'villerine yer verilmektedir.

\section{6. Hızır'ın Olayları Te'vili}

Kehf sûresinin 78. âyeti, Hızır'ın "Şimdi sana, sabredemediğin şeylerin içyüzünü haber vereceğim." şeklindeki vaadiyle bitmektedir. Sûrenin 79-82. âyetlerinde bu vadin yerine getirildiği ve olayların içyüzü hakkında Hızır tarafından bilgi verildiği görülmektedir.

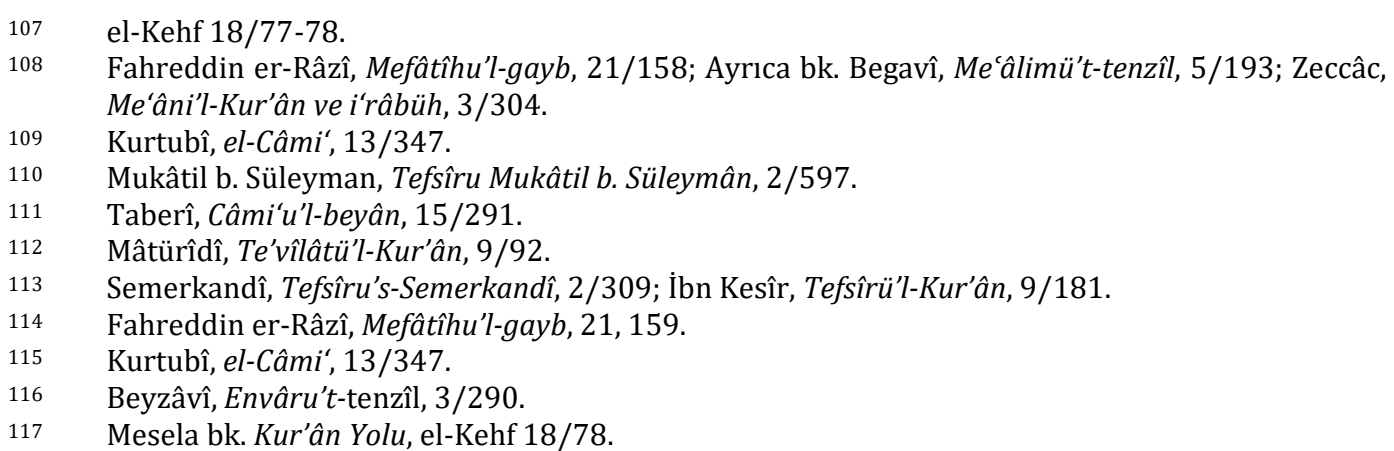




\section{6. 1. Hızır'ın Gemiyi Delmesinin Te'vili}

Hızır'ın açıklamasına göre, onun gemiyi delmesinin içyüzü şöyledir: Gemi, denizde çalışan yoksul kimselere aittir ve kendisi, onu kusurlu kılmak istemiştir. Çünkü onların arkasında, her gemiyi gasp eden bir kral bulunmaktadır. ${ }^{118}$

İbn Mes'ûd'un (ö. 32/652-53) kıraatinde ibare, "her sağlam (salih) gemiyi" şeklindedir. Mâtürîdî, “Bu kıraate göre âyetin te’vili, 'O kral gemiye el koymasın diye, onu ayıplı kıldım. Çünkü o, sağlam gemilere el koyuyordu.' olur." demektedir. ${ }^{119}$ "Her sağlam (salih) gemiyi” şeklindeki kıraati İbn Abbas'a nispet eden Semerkandî ise bu kıraatteki "salih" kelimesinin, "ayıbı olmayan" anlamına geldiğini ifade etmektedir.120 Görüldüğü üzere kıraat farklılıklarından da yararlanmak suretiyle müfessirler, sağlam gemilerin gasp edilmesi sebebiyle Hızır’ın gemiyi deldiğini ifade etmişlerdir.

Özellikle bazı müfessirlerin âyette bahsedilen olayla ilgili fıkhî çıkarımlarda bulundukları da göze çarpmaktadır. Mesela Semerkandî bu olaydan hareketle "Vasî, selamet gördüğü zaman yetimin malında tasarruf edebilir; örneğin yetimin nefis bir evi olsa ve bir sultanın ona tamah edeceğinden korksa o evin, bir bölümünü yıkabilir." hükmüne varmaktadır. ${ }^{121}$ Kurtubî de zikri geçen uygulamadan "maslahat yönü muhakkak olarak bilindiği takdirde maslahatla amel edilebileceği" ve "bir bölümünü ifsat etmek suretiyle malın tamamı kurtarılacaksa bunun câiz olduğu" sonuçlarına ulaşmaktadır. Ayrıca bu olayda, zorluk ve sıkıntılara sabretmenin teşvik edildiğini belirtmekte ve böyle hoşlanılmayan hallerde nice faydaların olabileceğini, Yüce Allah'ın "Bazen hoşlanmadığınız bir şey, sizin için hayırlı olur." 122 șeklindeki beyanına atıfta bulunarak ifade etmektedir. ${ }^{123}$

\section{6. 2. Hızır'ın Gulâmı Öldürmesinin Te'vili}

Hızır, gulâmı öldürmesini şu şekilde izah etmektedir: Gülâmın ana-babası, mümin kimselerdir. Onun, onları azgınlık ve nankörlüğe boğmasından korktuk. ${ }^{124}$

Gulâmın öldürülme sebebi, müfessirlere göre şunlardan biridir: Ya gulâm, bâliğ bir kâfirdir veya yol kesici bir hırsızdır ya da şu an için küçük olsa da bâliğ olduğu zaman kâfir olacaktır. Te'vîlât'ında bu izahlara değinen Mâtürîdî, Hızır'ın "Bunu kendiliğimden yapmadım."125 şeklindeki beyanı olduktan sonra gulâmın öldürülme sebebinin bilinmesine ihtiyaç kalmadığını ifade etmektedir. Ona göre bu durum, Allah'ın ölüm meleğine emretmesi sonucu onun bir küçüğü öldürmesine benzemektedir. Ayrıca âyette geçen "فَخَشَينَا" ifadesi, "bildik" anlamında kullanılmıştır

el-Kehf 18/79.

Mâtürîdî, Te'vîlâtü'l-Kur'ân, 9/92.

Semerkandî, Tefsîru's-Semerkandî, 2/309.

Semerkandî, Tefsîru's-Semerkandî, 2/309.

el-Bakara 2/216.

Kurtubî, el-Câmi', 13/351.

el-Kehf 18/80.

el-Kehf 18/82. 
ki Übey b. Kâ‘b'in kıraati de bu şekildedir. Buna göre Allah’ın kendilerinden her türlü şer ve zulüm tezahür eden zalimlere dair bilgisi olduğu halde onları terk edip helak etmemesi, O'nun beşeri imtihan etmesi ile açıklanabilir. Bu olayda ise katından bir lütuf söz konusu olmuştur. ${ }^{126}$ Bazı tefsirlerde Katâde'nin (ö. 117/735) şöyle dediği nakledilmektedir: Gulâm doğduğunda anne-babası sevinmişti. Öldürüldüğünde de onun için üzülmüşlerdi. Hâlbuki hayatta kalmış olsaydı, onların helak olmalarına sebep olacaktı. Bu bakımdan herkese düşen, yüce Allah'ın kazasına rıza göstermektir. Şüphesiz ki yüce Allah'ın, bir mümin hakkındaki -onun hoşuna gitmeyeni- takdiri, onun istediğini takdirinden daha hayırlıdır.127

\section{6. 3. Hızır'ın Duvarı Onarmasının Te'vili}

Hızır, yıkılmaya yüz tutmuş duvarı onarmasını ise şu şekilde açıklamaktadır: Duvar, şehirdeki iki yetim çocuğundur; duvarın altında da onlara ait bir hazine vardır. Çocukların babaları ise iyi bir kimsedir. Yüce Allah, o iki çocuğun güçlü çağlarına erişmelerini ve kendinden bir rahmet olarak hazinelerini çıkarmalarını, istemiştir. Hızır, bunu da kendiliğinden yapmamıștır. ${ }^{128}$

Mâtürîdî, âyette geçen kenz/hazine hakkında müfessirlerin farklı beyanları olduğunu ifade etmekte, hazinenin "çocukların babaları tarafından toprağa gömülmüş bir mal" veya "içerisinde ilim bulunan sayfalar" olduğunun beyan edildiğini nakletmektedir. Mâtürîdî’ye göre bu izahların telifi şu şekilde mümkündür: Rivayetlerdeki kenzin mal olduğuyla ilgili izahlar sabitse onun hem mal hem de ilim olması daha uygun olur. Bu da mesela üzerinde hikmetli sözler yazılı olan altın bir levha olabilir. Bunun bilinmesi çok da gerekli değildir. ${ }^{129}$ Tefsirlerde bu te'vil ile ilgili olarak şu konuya da dikkat çekilmiştir: Bu iki çocuk yedinci dedelerinin salihliği sebebiyle muhafaza edilmişlerdir. Demek ki Allah, mümin bir kulunun çocuk, torun ve zürriyetini korur. 130

\section{7. Olaylardan Çıkarılan Bazı İncelikler}

Müfessirlerin âyetlerde bahsedilen olaylarla ilgili bazı inceliklere değindikleri ve netice itibariyle çeşitli kaidelere ulaştıkları görülmektedir. Bunlardan bir kaçı şu şekildedir:

\section{7. 1. İşlerin Zâhiri ve Bâtını}

Bazı müfessirlerce ilgili âyetlerde bahsedilen konulardan yapılabilecek birinci çıkarım, olayların zâhire ve bâtına bakan veçhelerinin olduğudur. Râzî, bu hususu şu şekilde ifade etmektedir: Peygamberlerin hükümleri, zâhire göredir. $\mathrm{Bu}$

\footnotetext{
126 Mâtürîdî, Te'vîlâtü'l-Kur'ân, 9/93-94.

127 Taberî, Câmi'u'l-beyân, 16/4; Kurtubî, el-Câmi', 13/354; Begavî ise bu sözü Mutraf'a izafe etmektedir. bk. Begavî, Me âlimü't-tenzîl, 5/195.

el-Kehf 18/82.

Mâtürîdî, Te'vîlâtü'l-Kur'ân, 9/96.

Mâverdî, en-Nüket ve'l-'uyûn, 3/336; Begavî, Me âlimü't-tenzîl, 5/196; İbnü'l-Cevzî, Zâdü'l-mesîr, 5/182; Fahreddin er-Râzî, Mefâtîhu'l-gayb, 21/163; Kurtubî, el-Câmi', 13/356.
} 
âlimin ahkâmı ise durumun özünde vaki olan hakiki sebeplere göre vazedilmiştir. Çünkü görünen, her iki olayda da bu eylemi câiz hale getiren belirgin bir husus olmaksızın, insanların malları ve canları konusunda girişimde bulunmayı yasaklamaktadır. Zâhir bir sebep bulunmadan gemide delik açmak, bir insanın mülkünü azaltmak anlamına gelir. Görünen bir sebep olmadan çocuğu katletmek de masum bir canı öldürmek manasına gelir. Üçüncü olayda konu edilen "yıkılmak üzere olan duvarı doğrultmak" ise belirgin bir sebep yokken, bir zahmet ve külfet altına girmek demektir. Bu üç olayda o âlimin hükmü, bilinen ve görünen sebeplere göre olmamıştır. Tam tersine, işlerin özünde olup itibar edilmesi gereken sebeplere bina edilmiştir. Bu ise Allah'ın o âlime, kendisiyle olayların derinliklerini keşfedebileceği ve varlıkların hakikatlerine muttali olabileceği akli bir kuvve ihsan ettiğini göstermektedir. ${ }^{131}$

\section{7. 2. Zararlılar Arasında Tercih}

Müfessirlerin bir kısmına göre Mûsâ-Hızır kıssasında işaret edilen diğer bir esas da iki zararla karşılaşıldığında daha zararlı olanı uzaklaştırmak için daha az zararlı olanı üstlenmek gerektiğidir. Râzî, zikri geçen üç meselede nazar-ı dikkate alınan temel düsturun bu olduğunu söylemektedir. Mesela birinci meselede gemiyi delmenin vereceği zarar, kralın onu gaspının doğuracağı zarardan daha hafiftir. İki zarardan daha büyügünü defetmek için diğerini yapmak gerekmiştir. İkinci meselede ise gulâmın hayatta kalması, ana-babası için din ve dünyalarını fesada uğratacak bir meseledir. O âlim, bu çocuğun öldürülmesinin ana-babasının fesadından daha az zararlı olduğu bilgisine vahiy yoluyla ulaşmış ve bu sebeple onu öldürmeye yönelmiştir. Üçüncü meselede ise duvarı düzeltmeden dolayı meydana gelen külfetin yol açtığı zarar, o duvarın yıkılmasından meydana gelecek zarardan daha hafiftir. 132

\section{7. 3. İrade Fiillerindeki Şahıs Değişikliğinin İzahı}

Müfessirlerin dikkatini çeken hususlardan biri de Hızır'ın üç olayla ilgili izahları yaparken irade fillerini, farklı faillere nispet etmesidir. Hızır'ın bu beyanları ile ne kastetmiş olabileceği üzerinde duran müfessirler, özellikle kullanımın hikmetine yönelik izahlarda bulunmaya çalıșmışlardır. Râzîye göre o âlim, "kusurlu kılma" işinden bahsederken bunu dilemeyi, kendisine nispet etmiştir. Öldürme işinden bahsederken ise "Diledik." diyerek çoğul kalıbını kullanmış ve böyle bir işe ancak yüce bir hikmetten ötürü teşebbüs ettiğini anlatmak istemiştir. Ataların hakkını gözeterek çocukların faydasına olan işleri tekeffül edenin ise ancak Allah olduğunu belirtmek için duvarı düzeltme işini anlatırken de iradeyi, Allah'a nispet etmiştir. ${ }^{133}$

\footnotetext{
131 Fahreddin er-Râzî, Mefâtîhu'l-gayb, 21/160.

132 Fahreddin er-Râzî, Mefâtîhu'l-gayb, 21/160.

133 Fahreddin er-Râzî, Mefâtîhu'l-gayb, 21/163.
} 
Kurtubî ise bu konuda şöyle bir izahta bulunmaktadır: "Hızır duvarın düzeltilmesi konusunda iradeyi, yüce Allah'a nispet etmiştir. Çünkü ilgili mesele, uzun bir zaman sonra meydana gelecek gaybî bir olaydır ve Hızır’a böyle bir iradede bulunmayı öğreten Allah'tır." Yine Kurtubî'nin naklettiğine göre bu hususla alakalı olarak yapılan diğer bir izah da şu şekildedir: "Duvarın düzeltilmesi tamamıyla hayır bir iş olduğundan dolayı, Hızır onu yüce Allah'a izafe etmiştir. Geminin kusurlu kılınmasını da edebe riayet ederek kendi nefsine nispet etmiştir. Çünkü yüce Allah'a ancak güzel görülen şeyler nispet edilir, çirkin görülenler nispet edilmez. Çocuk hakkında da "Diledik." ifadesini kullandığı görülmektedir. Bu ifade ile öldürmeyi kendine, onun yerine daha hayırlı birisini vermeyi de yüce Allah'a nispet etmiş gibidir. ${ }^{134}$

\section{8. Kıssadaki Bazı İfadelerin İşarî Te'vili}

Kıssadaki üç hadise, netice itibariyle bizzat Hızır tarafından te'vil edilmektedir. Hızır'ın bu izahları, ne dilin imkânları ve tarihi verilerle ne de gaibin şahide kıyası ile yapmadığı görülmektedir. Aksine Hızır'ın te'villerini, işlerin arka yüzüne veya zâhirin ötesinde var olan bir yapıya dayandırdığı anlaşılmaktadır. İşte özellikle kıssadaki bu durumun, irfan ehline hüccet/delil olduğu ve onları hem bu beyanları hem de başka âyetleri işârî te'vile sevk ettiği söylenebilir. İrfanî yöntemi kullanan müfessirlerin, Mûsâ-Hızır kıssasında geçen bazı kavramları izahları şöyledir:

\section{8. 1. İlm-i Ledün}

Her ne kadar "ledün” tabiri, kelime yapısı itibarıyla 'yanında, katında'135 anlamına gelen bir zarf ise de Elmalılı’nın da işaret ettiği gibi kıssanın içeriği ve konuyla ilgili rivayetlerin de katkısıyla gelenek içinde ilm-i ledün, bâtınî/vehbî ilmi veya gayb bilgisini ifade eden bir terim haline gelmiştir. ${ }^{136}$ Yoksa Kur'ân'ın bu bilgi türünü bu zarf ile terim haline getirdiği söylenemez.

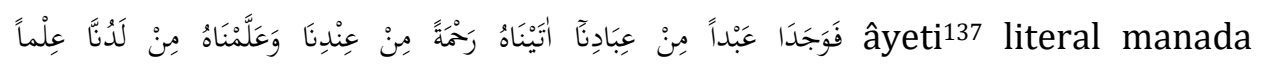

okunduğunda, direkt olarak "ilm-i ledün" kavramı ortaya çıkmamaktadır. Bununla birlikte yüce Allah, bu âyet içinde "kula verdiği ilim ve rahmeti" anlatırken beş kez birinci çoğul şahıs zamiri kullanarak her şeyi zatına izafe etmektedir. Kıssadaki iki anahtar beyandan biri, bu ifadedir. İkinci anahtar beyan ise âyette Hızır'a nispetle ifade edilen, "Bunu, kendiliğimden yapmadım."138 sözüdür. İlk âyetteki gramatik yapı, işârî anlamın meşruiyetine delil olarak gösterilebilir. Ekseriyetle nübüvvet olarak yorumlanan "rahmet" ifadesinden sonra ayrıca ilmin öğretilmesi ve bu

134 Kurtubî, el-Câmi', 13/357.

135 Halîl b. Ahmed, Kitâbu'l-'Ayn, thk. Abdulhamîd Hendâvî, (Beyrut: Dârü'l-Kütübi'l-'Ilmiyye), "Idn", 4/416; İsmâil b. Hammâd el-Cevherî, es-Sihâh: Tâcü'l-luga ve sihâhu'l-'Arabiyye, nșr. Halîl Me'mûn Şeyhâ (Beyrut: Dârü'l-Ma'rife, 2007), “ldn”, 943.

136 Elmalılı, Hak Dini, 5/3262.

137 el-Kehf $18 / 65$.

138 el-Kehf 18/82. 
talimin "ledünnâ" kaydıyla tahsisi Âlusî̀nin (ö. 1270/1854) de dikkat çektiği gibi söz konusu bilgi türünün elde edilişinin hususî bir şekilde, vasıtasız, kalbe ilham ve keşf yoluyla olduğuna dair izahlar1 ${ }^{139}$ teyit etmekte ve anlamlı kılmaktadır. ${ }^{140}$ Mesela Gazzâlî (ö. 505/1111), ledün ilminin sadece insanın öğrenimiyle elde edilemeyecek bir ilim mertebesi olduğunu ifade eden müelliflerdendir. Ona göre Allah bir kulu hakkında hayır dilediği zaman onunla levh arasındaki hicabı kaldırmakta ve o kul, gizli bazı sırlara mazhar olarak Allah'ın dilediği kullarına o sırlardan bahsetmektedir. ${ }^{141}$ Tefsîru İbni'l-'Arabî̀de de ledün ilminin, beșerin talimi ile gerçekleşmeyen bir yapıda olduğu vurgulanmaktadır.142 Bu ilme ulaşmak için "bâtını arındırılmak, nefsi yalnız bırakmak ve kalbi zâhiri alakalardan temizlemek" gerekir. ${ }^{143}$ Allah tarafından verilen bu özel ilme kul, organlarını muhalefet etmekten koruyarak ve Hakk'ın huzurunda temennide bulunmayan bir hayal olmak suretiyle erişebilir. Diğer bir izaha göre ilm-i ledün, Allah'ın velilerine kullarının iyiliğine olan şeyleri bildirmesidir. ${ }^{144}$ Bütün bu izahlara göre ilm-i ledün; özellikle de tahsili yönüyle sadece beșeri gayrete bina edilen, bilinen ve yaygın olan ilim tahsilinden ayrılmaktadır.

$\mathrm{Bu}$ konuda bir risale kaleme alan Gazzâlî, ilham sonucu hâsıl olan ilme "ledünnî ilim" denildiğini ifade etmektedir. Kaynak itibarıyla aynı olan vahiy ile ilham arasında ise şöyle bir farkın olduğunu dile getirmektedir: Vahiy gaybî bir emrin beyan edilmesi, açıklanmasıdır. İlham ise gaybî bir emrin kapalı bırakılması, lisandan ziyade işaretle meramın anlatılmasıdır. ${ }^{145}$ Dolayıyla ilhamda ve de ilm-i ledünde sembolik bir dil kullanımı söz konusudur. Neticede ise bu ilimde, tıpkı rüyalarda olduğu gibi te'vile ihtiyaç duyulmaktadır.

\section{8. 2. Mecmau'l-Bahreyn}

Kıssada irfanî te'vil bakımından incelenmesi gereken en önemli sembollerden biri de "mecmau'l-bahreyn" ifadesidir. "İki denizin birleștiği yer"

139 bk. Muhammed b. Hüseyin es-Sülemî, Hakâiku't-Tefsîr, thk. Seyyid İmrân (Beyrut: Dâru'lKütübi'l-'Ilmiyye, 1421/2001), 1/414; Nizâmüddîn Hasen b. Muhammed en-Nîsâbûrî, Garâi'bü'l-Kur'ân ve regâi'bü'l-furkân, nşr. Zekeriyyâ Umeyrât (Beyrut: Dâru'l-Kütübi'l-'Ilmiyye, 1416/1996), 4/454.

140 Âlûsî, Rûhu'l-me ânî, 15/330.

141 Ebû Hâmid Muhammed el-Gazzâlî, er-Risâletü'l-ledünniyye (Mecmuatü resâili'l-İmâmi'l-Gazzâlî içinde) nşr. İbrâhîm Emîn Muhammed (Kahire: el-Mektebetü't-Tevfîkıyye, ts.), 250.

142 Muhyiddin Muhammed b. Ali el-Arabî, Tefsîru İbni'l-'Arabî (b.y.: y.y., 1231/1816), 1/406. Bu eserin bazı yazmalarında Te’vîlâtü'l-Kur'ân adıyla Abdürrezzâk b. Muhammed el-Kâşânîye (ö. 736/1335) nispet edildiği görülmektedir. Mesela bk. Abdürrezzâk b. Muhammed el-Kâşânî, Te’vîlâtü'l-Kur'ân (Riyad: Kral Soud Üniversitesi, Yazmalar, 2437), 305a; Eserin yanlışlıkla İbnü'l-Arabî’ye nisbet edilip Tefsîru İbni'l-'Arabîadıyla defalarca basıldığından bahseden Süleyman Uludağ da "eserin geniş ölçüde İbnü'l-Arabî̀nin geliştirdiği kavram ve terimlere dayalı bir tasavvufî tefsir" olduğuna dikkat çekmektedir. bk. Süleyman Uludağ, "Kaşânî, Abdürrezzâk", Türkiye Diyanet Vakfi İslâm Ansiklopedisi (Erişim 25 Ekim 2020). Eserin İbnü'lArabî̀ye nispeti de zikri geçen özelliğinden kaynaklanmış olabilir. Bu sebeple eser buradan itibaren sadece Tefsîru İbni'l- 'Arabî olarak ifade edilecektir. Fahreddin er-Râzî, Mefâtîhu'l-gayb, 21/161.

Âlûsî, Rûhu'l-me ânî, 16/22.

Gazzâlî, er-Risâletü'l-ledünniyye, 250. 
manasına gelen bu ifade işârî olarak ne anlama gelmektedir? Tefsîru İbni'l-'Arabî̀de mecmau'l-bahreyn, âlem-i ruh ve âlem-i cismin birleștiği yer olarak te'vil edilmektedir. 0 iki (âlem) ise insaniyet suretinde tatlı ve tuzlu (deniz) olarak bulunmaktadırlar. Mecmau'l-bahreyn, kalp makamıdır. (Diğer bir açıdan) Mûsâ kalbi, fetâ nefsi, salih kul yahut Hızır ise akl-i kutsîyi temsil etmektedir. ${ }^{146}$

İrfanî yönde yapılan izahlara göre "mecmau'l-bahreyn" terkibindeki iki deniz ile Mûsâ ve Hızır'a işaret edilmektedir. Onlara ilimlerinin çokluğu sebebiyle bahr/deniz denilmiştir. Onlardan Mûsâ, zâhir ve bâtın denizidir ancak kendisinde zâhir yani şeriat galiptir. Hızır da zâhir ve bâtın denizidir. Onda ise bâtın yani hakikat galip gelmiştir. Onların buluştukları yer ise muayyen bir mekân değil birleşmelerine uygun düşen mekândır. ${ }^{147}$ Mecmau'l-bahreyn, seyr-i sülûk açısından ise mürid ile şeyh arasındaki velayetin simgesidir. Mürid, şeyhin velayetinin birleşme yerine ulaşmadıkça onun sohbetinden faydalanamaz. Velayetin birleşme yerinde hakiki hayat suyu vardır. Bu pınarın müride sıçrayan ilk katresiyle müridin kalbi dirilir ve velayet denizinde yol almaya başlar.148 Mürid, şeyhin velayeti olmaksızın yola koyulursa çok meşakkate maruz kalır ve maksadına erişemez. Mürşidin terk edilmesi, şeytanın musallat olmasına ve hizlâna düşmeye sebep olur. ${ }^{149}$

\section{8. 3. Hût}

Mûsâ-Hızır kıssasında geçen ve irfanî olarak izah edilen kavramlardan biri de hût/balık kelimesidir. Bu izahlara göre Hz. Mûsâ ile yol arkadaşının yanlarına aldıkları tuzlanmış balık, insan kalbini sembolize etmektedir ki bu kalp nefsin şehvetleriyle öldürülmüş, sonrasında da dünya ve süslerinin muhabbetiyle tuzlanmış bir halde bulunmaktadır. Sonuç itibariyle mürid mürşidin velayetine eriștiğinde, hakikatin hayat kaynağından kendisine isabet edecek bir damla ile müridin balık mesabesindeki kalbi tekrar canlanıp velayet okyanusunda bir yol bulacaktır. "Allah, bir kimse ile onun kalbinin arasına girer."150 âyetinin esrarı gereğince mürid şeyhi kaybettiğinde balığını yani kalbini unutur. Kalp ise şeyhi bulduğunda müridi unutur. ${ }^{151}$

\section{8. 4. Sefine/Gemi}

Âyet-i kerîmede anlatıldığına göre Hızır, bindikleri gemiyi delmiş veya yaralamıştı. Eşyanın hakikati ve nefsü'l-emirdeki mahiyeti, ilm-i ilâhîye dair yönü anlamındaki ilm-i ledünne dair ilk ders niteliğindeki bu hadise, irfanî gelenekçe nasıl yorumlanmıştır?

\footnotetext{
146 Tefsîru İbni'l- 'Arabî, 1/404-406.

147 Bursevî, Rûhu'l-beyân, 5/263.

148 et-Te'vîlâtü'n-Necmiyye, 4/143; Bursevî, Rûhu'l-beyân, 5/266.

149 Bursevî, Rûhu'l-beyân, 5/267.

150 el-Enfâl 8/24.

151 et-Te'vîlâtü'n-Necmiyye, 4/143; Bursevî, Rûhu'l-beyân, 5/266.
} 
İşârî tefsirlerden olan 'Arâ'isü'l-beyân'da ve Tefsîru İbni'l- 'Arabî̉de bu gemi seyahati, kulluk için riyâzet ${ }^{152}$ yapmaya uygun pozisyondaki beden gemisine binerek kutsal diyara doğru yola koyulmak olarak yorumlanmaktadır ki bu durum, Bahr-i Heyûlâ'da Allah'a yolculuktur. Geminin yaralanması ise bedenin az yemek yeme gibi riyâzete dair hususlarla terbiye edilmesidir. Bunun neticesinde bedeni kuvvelerin kırılması ve heyûlâ denizinde gark olması söz konusu olacaktır. Hz. Mûsâ'nın "Çok kötü bir iş yaptın!” şeklindeki beyanı ise Rûzbihân el-Baklî̀ye (ö. 606/1209) göre "Bu bedeni kuvvelerle ulaşılan cüzi șeyler vasıtasıyla külli manalara yol bulunabilir." anlamına gelirken Tefsîru İbni'l-'Arabî̀ye göre nefsin riyâzete karşı koyan yapısını ifade etmektedir.153 Nizâmüddîn en-Nîsâbûrî (ö. 730/1329 [?]) ise âyette geçen sefineyi şeriat olarak te'vil etmektedir. Geminin delinmesi de tıpkı kıssada olduğu gibi zahiren dinin ifsadı, nâmusun (kanunun) zayi edilmesi gibi görünse de bâtınî açıdan ıslahtan başka bir şey değildir. Gemi ehlinin batırılması ise onların dalalet denizine atılmalarını sembolize etmektedir. Diğer bir açıdan melik, şeytanı temsil etmekte, gemi ise ibadeti sembolize etmektedir. Şeytanın ibadetleri ele geçirmesinden korumak, gemiyi ayıplı hale getirmek yani bâtında ihlaslı olmak ile mümkündür. Çünkü inkisar, boyun eğme ve huşûsu olmayan ibadetler Rahman için değil şeytan için olur. ${ }^{154}$

\section{8. 5. Çocuğun Öldürülmesi}

Kıssada sembolik dil açısından önemli figürlerden birisi de bir oğlan çocuğunun Hızır tarafından öldürülmesidir ki kıssanın sonunda bu davranışın ilm-i ilâhîye bakan yönünü açıklayan da bizzat Hızır olmuştur.

Tefsîru İbni'l-'Arabî'de Hızır ile Mûsâ'nın rastladıkları çocuk nefs-i emmâre155 olarak değerlendirilmekte, onun katli de gazap ve şehvet gibi kuvvelerin öldürülmesi olarak te'vil edilmektedir. Yine bu tefsirde Hz. Mûsâ'nın “Masum bir cana mı kıydın?" şeklindeki itirazı, kalbin nefse acıması ve merhameti şeklinde yorumlanırken "kendisine sabredemeyeceği" hatırlatıldığında "Bundan sonra eğer sana soru sorarsam benimle arkadaşlık etme!" diyerek özür beyan etmesi ise nefs-i levvâmeye ${ }^{156}$ ait telvinat olarak te'vil edilmektedir. ${ }^{157}$ Nîsâbûrî de bu göstergeyle ilgili olarak çocuğun nefs-i emmâreyi temsil ettiğini belirtmektedir. Onun katledilmesi ise riyâzet bıçağıyla ve mücâhede kılıcıyla öldürülmesi manasına

\footnotetext{
152 Nefsi, ahlaki güzelliklere eriştirmek için yapılan çalışmalardır. bk. es-Seyyid eş-Şerîf Ali b. Muhammed el-Cürcânî, et-Ta'rîfât, thk. Muhammed Abdurrahman el-Mer'aşlî (Beyrut: Dâru'nNefâes, 1424/2003), 183.

153 Baklî, 'Arâ'isü'l-beyân, 2/433; Tefsîru İbni'l-'Arabî, 1/406.

154 Nîsâbûrî, Garâi'bü'l-Kur'ân, 4/454-455; Âlûsî, Rûhu'l-me`ânî, 16/23.

155 Kelime anlamı, emredici nefistir. Terim olarak ise bedenî tabiata meyleden, lezzetleri ve hissî şehvetleri körükleyen ve kalbi, şerrin ve kötü ahlakın kaynağı olan süflî (aşağılık) şeylere çeken nefistir. bk. Abdürrezzâk el-Kâşânî, Istılâhâtü's-sûfiyye, thk. Abdulâl Şâhîn (Kahire: Dâru'lMenâr, 1413/1992), 115.

156 Kelime anlamı, kınayıcı nefistir. Terim olarak ise Mevla'sına itaatteki kusurundan dolayı sahibini kınayan, şehvani isteklere uymakla birlikte onlara karşı gelmeye çalışan nefis demektir. bk. Cürcânî, et-Ta'rîfât, 235.

157 Tefsîru İbni'l- 'Arabî, 1/407.
} 
gelmektedir. Öldürülen gulâmın anne ve babası ise kalp ve ruhu, o gulâmın yerine ihsan edilecek olan daha hayırlı çocuk ise nefs-i mutmainneyi158 sembolize etmektedir. ${ }^{159}$

\section{8. 6. Duvar}

Kıssadaki Hızır'ın yıkılmaya yüz tutmuş bir duvarı düzeltmesinden bahseden kısım da sûfî gelenekte işârî te'vil anlayışıyla yorumlanan bölümlerdendir. Buna göre Mûsâ ile Hızır'ın uğradıkları șehir cesedi, şehir sakinleri de bedenî kuvveleri temsil etmektedir. Mûsâ ile Hızır, onlar vasıtasıyla ruhanî manada gıdalanmayı istemektedirler. Yıkılmaya yüz tutmuş duvar, nefs-i nâtıka ${ }^{160}$ ile âlem-i mücerredât arasında kopmaya yüz tutmuş alakayı temsil etmektedir. Onun düzeltilmesi ise bedeni kuvvetlendirmek ve kuvveler ile duyulara yumuşaklıkla muamele etmek demektir. Zira "Nefsin senin bineğindir, ona yumuşak davran!" denilmiştir. Ücret talebi, füyûzât-ı envâra ve keşfiyyâta nail olmak için riyazâtın şiddeti karışışında sabır istemektir. Duvarın altındaki kenz ise kemâlât-ı nazariyye ve ameliyyedir. ${ }^{161}$

Tefsîru İbni'l-'Arabî̉ de ise ilgili bölüm, şöylece te'vil edilmiştir: Yıkılmaya yüz tutmuş duvar, mutmainne nefsi sembolize etmektedir. Onun duvar olarak ifade edilmesi, nefsi emmârenin riyâzet ile öldürülmesinden sonra ortaya çıkması dolayısıyladır. 0 mutmainne nefis, kendi başına hareket etmeyen bir duvar gibidir âdeta. Şiddetli zayıflı̆̆ sebebiyle de helak olmaya yüz tutmuştur. Onun doğrultulması, nutuk kuvvesinin nuruyla yaratılışa ait kemâlât ile düzeltilmesi demektir ki böylece bayağı vasıfların yerini faziletler alır. Babalarını kaybetmiş çocuklar da nazarî ve amelî olan iki âkıledir. Onların yitirdikleri baba ise Rûhulkudüs'tür. Yetimlik de bedenî örtülerle Rûhulkudüs'ten perdelenmektir. Diğer bir yoruma göre âyette geçen salih baba, nefsin beden şehrini ele geçirmesi sonucunda kemâle erişmeden ölen/öldürülen kalbi sembolize eder. Duvar altında bulunan kenz ise mârifet hazinesidir. ${ }^{162}$

\section{Sonuç}

Mûsâ Hızır kıssası, yaşanan bir gerçekliğe tekabül etmekte ve Hz. Mûsâ'ya ait özel bir tecrübeden bahsetmektedir. Bir mesel veya yaşanmamış bir kurgu olduğunu söylemek ancak gayba taş atmak demektir. Kehf sûresinde anlatılan Mûsâ-Hızır kıssası, yine aynı sûrede zikredilen Ashâb-ı Kehf kıssası ve Zülkarneyn kıssası gibi müteşâbih ve ilginç bir yapıya sahiptir. Bu üç kıssanın anlatımındaki ortak nokta, Allah'ın büyük lütuflarda bulunduğu bazı kişilere kendi katından rahmet ve özel yetkiler vermesidir.

\footnotetext{
158 Kelime anlamı, tatmin olmuș nefistir. Terim olarak ise ilâhî emirler altında sakin olmuș ve şehvetlere karşı çıkmak suretiyle ıztıraptan kurtulmuş nefis anlamına gelmektedir. bk. Cürcânî, et-Ta'rîfât, 235.

159 Nîsâbûrî, Garâi'bü'l-Kur'ân, 4/454-455.

160 Zatında maddeden mücerret olmakla birlikte yaptığı işlerde, maddeye bitişik olan bir cevherdir. bk. Cürcânî, et-Ta'rîfât, 235.

161 Nîsâbûrî, Garâi'bü'l-Kur'ân, 4/454; Âlûsî, Rûhu'l-mecânî, 16/23.

162 Tefsîru İbni'l-'Arabî, 1/407-409.
} 
Klasik tefsirlerin ekseriyetle kıssayı beyanî te'vil metoduyla yorumladıkları müşahede edilmektedir. Mesela tefsirlerde, kıssadan hareketle "İstitâat, fiille birlikte midir yoksa fiilden önce midir?" gibi sorular sorulup cevaplar verilmiștir. Yine kıssada geçen şahısların kimlikleri ve sıfatları üzerinde durulmuştur. Özellikle şahısların sıfatları ile ilgili yorumların, daha çok Hızır'ın ortaya koyduğu faaliyetlerin Kelam ve Fıkıh İlmi çerçevesinde izahını mümkün kılmaya yönelik olduğu görülmektedir. Bununla birlikte çoğu müfessir de kıssaya, belki de kıssanın yapısı icabı, manevi veçheden bakmak durumunda kalmıştır. Bunun neticesi olarak da genellikle tefsirlerde "kıssada ilim öğrenmenin gerekliliğine ve edeplerine işaret edildiği" ve "Hızır'ın ilminin ilm-i bâtın olduğu" gibi hususlar dile getirilmiștir. Kıssada geçen "iki denizin birleştiği yer" gibi beyanlar da genellikle beyanî tefsir metodunu tercih eden müfessirler tarafından maddi olarak açılanmıştır. $\mathrm{Bu}$ bağlamda onların, "mecmau'l-bahreyn" ile ilgili yer tayininde bulundukları görülmektedir. İrfanî yönde yapılan izahlara göre ise iki deniz ile Mûsâ ve Hızır'a işaret edilmektedir. İrfanî te'vilde mecmau'l-bahreyn, âlem-i ruh ve âlem-i cismin birleştiği yer olarak da belirtilmiștir. Özellikle 'Arâ'isü'l-beyân gibi tefsirlerde kıssanın zâhir olan kısmı bile bâtınî bir şekilde açıklanmıştır. Buradan hareketle Kur'ân âyetlerinin müfessirin esas aldığı yönteme göre izah edildiği, genellikle beyanî olarak ve bazı tefsirlerde irfanî metotla yorumlandı̆̆ı söylenebilir.

Kıssa; bütün Kur'ân kıssalarında olduğu gibi başta Hz. Peygamber'i, onun şahsında da bütün Müslümanları teselli eden ve eğiten bir yapıyı haizdir. Kıssada anlatılan üç olayla ilgili olarak şöyle bir çıkarımda bulunmak mümkündür: Yüce Allah müminlerin arkasındadır, onların başlarına gelen ve görünüş itibariyle hoş olmayan durumlarda bile nice hayırlar mevcuttur. Mümin kul, her hâlükârda yüceler yücesi Allah'a sonsuz teslimiyet ve güven içerisinde olmalıdır. Öte taraftan kıssadaki Hz. Mûsâ'ya ait itirazvari girişimler; bir müminin, gördüğü bir münker karşısında kayıtsız kalamayacağını da göstermektedir. Ancak mümin, görünen her şeyin göründüğü gibi olamayabileceği şuuruyla hareket edip fevri davranmamalı, gerektiğinde geri adım atmalıdır. Şüphesiz her şey, yüce Allah'ın kontrolündedir ve 0 , her şeyi görüp gözeten bir hâkimiyete sahiptir.

Genel olarak tefsirlerde Hızır'ın filleri, Allah'ın emri ve takdiriyle ilişkilendirilmiş ve neticede Allah'ın takdirinde kulların tespit ve tayinden aciz kaldıkları pek çok hayrın bulunduğu beyan edilmiştir. Hızır'ın üç olayla ilgili izahları yaparken irade fillerini, farklı faillere nispet etmesi de müfessirler tarafından özellikle kullanımın hikmetine yönelik olarak açıklanmıştır. Çağdaş bir araştırmada da belirtildiği gibi kıssada, ilm-i ledün sahibi kişiden ziyade Allah'ın ilminin kapsayıcılığına vurgu yapılmaktadır. Aynı zamanda kıssada, varlığın ve hakikatin farklı bir boyutuna işaret edilmektedir. $\mathrm{Bu}$ nedenle kıssa hakkındaki irfanî yorumların da dikkate alınması yerinde olur. Zira Elmalılı'nın da ifade ettiği üzere bu kıssa, bir zâhir-bâtın kıssasıdır.

Netice itibariyle özetlemek gerekirse Yûsuf kıssasıyla da benzerlik arz eden Mûsâ-Hızır kıssası, sırrı teklif ve kadere vurgu yapan yönleri ile farklı bir boyutta 
457 | Klasik Tefsir Hareketlerinin Mûsâ-Hızır Kıssası Bağlamında Mukayesesi

cereyan etmiş bir tecrübeyi anlatmaktadır. İlgili âyetlerde Hızır'ın fiillerine sadece Mûsâ'nın tepkilerinin zikredilmesi ve müfessirlerin onları diğer insanların görmediğine dair kayıtları da bunu destekler mahiyettedir. Hz. Mûsâ'ya ait bu ilâhî tecrübe, bir açıdan Hz. Peygamber'in mi'râc tecrübesine benzetilebilir. 


\section{Kaynakça}

Ahmed b. Hanbel, Ebû Abdillâh Ahmed b. Muhammed b. Hanbel eş-Şeybânî. el-Müsned. nşr. Bedreddin Çetiner. 6 Cilt. İstanbul: Çağrı Yayınları, 2. Basım, 1413/1992.

Albayrak, Halis. İnsan-Gayb İlişsisi. İstanbul: Şule Yayınları, 1993.

Âlûsî, Şehâbeddîn Mahmûd. Rûhu'l-me'ânî fí tefsîri'l-Kur'âni'l-'azîm ve's-seb 'i'l-mesânî. 30 Cilt. Beyrut: Dâru İhyâi't-Türâsi'l-'Arabî, ts.

Arslan, Sevim. "Hz. Musa ve Hızır Kıssası Üzerine Bir Değerlendirme". Toplum Bilimleri Dergisi, 12/24 (Temmuz 2018), 161-176.

Atılgan, Yusuf Kenan. Ledünni İlmin Hz. Musa-Hızır Kıssası Bağlamında Kelami Açıdan Değerlendirilmesi. Sivas: Cumhuriyet Üniversitesi, Sosyal Bilimler Enstitüsü, Yüksek Lisans Tezi, 2017.

Aynî, Ebû Muhammed Bedrüddîn. Umdetül-kâri fî șerhi Sahîhi'l-Buhârî. nşr. Abdullah Mahmûd Muhammed Ömer. 25 Cilt. Beyrut: Dâru'l-Kütübi'l-Ilmiyye, 1421/2001.

Baklî, Rûzbihân b. Ebî Nasr. 'Arâ'isü'l-beyân fỉ hakâ'ikı'l-Kur'ân. thk. Ahmed Ferîd el-Mezîdî. 3 Cilt. Beyrut: Dâru'l-Kütübi'l-'Ilmiyye, 1429/2008.

Bardakçı, Necmeddin. Hakikatin Keşfi Hz. Musa ve Hızır. İstanbul: Rağbet Yayınları, 2016.

Bardakçı, Necmeddin. "Îsmail Hakkı Bursevînnin Musa-Hızır Kıssası Yorumunun İlim-Marifet Uygunluğu Açısından Değerlendirilmesi”. Süleyman Demirel Üniversitesi İlahiyat Fakültesi Dergisi 5 (1998), 81-103.

Barlak, Muzaffer - Özdemir, Faruk. "Mûsâ-Hızır Kıssasının Allah'ın İlkeli Bir Varlık Oluşu Çerçevesinde Değerlendirilmesi", Journal of Islamic Research 27/3 (2016), 353-371.

Begavî, Ferrâ. Me'âlimü't-tenzîl. thk. M. Abdullah en-Nemr vd. 8 Cilt. Riyad: Dâru Tayyibe, $1409 / 1988$.

Beyzâvî, Nâsırüddîn Ebû Saîd Abdullah b. Ömer. Envâru't-tenzîl ve esrâru't-te'vîl, Dâru İhyâi'tTürâsi'l-'Arabî. 5 Cilt. Beyrut ts.

Buhârî, Ebû Abdillâh Muhammed b. İsmail. el-Câmi'u's-sahîh. nşr. Bedreddin Çetiner. 8 Cilt. İstanbul: Çağrı Yayınları, 2. Basım, İstanbul 1413/1992.

Bursevî, İsmâil Hakkı. Rûhu'l-beyân. 10 Cilt. İstanbul: el-Matbaatü'l-Osmâniyye, 1330/1911.

Câbirî, Muhammed Âbid. Arap-İslam Kültürünün Akıl Yapısı. çev. Burhan Köroğlu vd. İstanbul: Kitabevi, 1999.

Cebecioğlu, Ethem. "Niyaz-ı Mırrî̀ye Göre Hz. Musa ve Hızır Kıssası: Çocuğun Öldürülmesi”. Akademiar Dergisi 1 (2016), 49-78.

Cevherî, İsmâil b. Hammâd. es-Sihâh: Tâcüll-luga ve sihâhu'l-'Arabiyye. nşr. Halîl Me'mûn Şeyhâ. Beyrut: Dârü'l-Ma'rife, 1427/2007.

Cürcânî, es-Seyyid eş-Şerîf Ali b. Muhammed. et-Ta'rîfât. thk. Muhammed Abdurrahman elMer'aşlî. Beyrut: Dâru'n-Nefâes, 1424/2003.

Elmalılı, Muhammed Hamdi Yazır. Hak Dini Kur'ân Dili. 10 Cilt. İstanbul: Eser Neşriyat, ts.

Ezherî, Muhammed b. Ahmed. Tehzîbü'l-luga. thk. Muhammed Ali en-Neccâr vd. 15 Cilt. Beyrut: ed-Dâru'l-Mısriyye, 1383/1964.

Gazzâlî, Ebû Hâmid Muhammed. er-Risâletü'l-ledünniyye (Mecmuatü resâili'l-İmâmi'l-Gazzâlî içinde). nşr. İbrâhîm Emîn Muhammed, Kahire: el-Mektebetü't-Tevfîkıyye, ts.

Harman, Ömer Faruk. "Mûsâ". Türkiye Diyanet Vakfi İslâm Ansiklopedisi. Erişim 5 Mart 2020. https://islamansiklopedisi.org.tr/musa--peygamber

Halîl b. Ahmed, Ebû Abdirrahmân el-Ferâhîdî. Kitâbu'l-'Ayn müratteben alâ hurûfi'l-mu'cem. thk. Abdulhamîd Hendâvî, 4 Cilt. Beyrut: Dâr'ül-Kütübi'l-'Ilmiyye, 1422/2002. 
İbn Atıyye, Ebû Muhammed Abdülhak b. Gâlib b. Abdirrahmân el-Endelüsî. el-Muharrerü'lvecîz fî tefsîri'l-kitâbi'l-'azîz. thk. Abdüsselâm Abdüşşâfî Muhammed. 6 Cilt. Beyrut: Dâru'l-Kütübi'l-'Ilmiyye, 1422/2001.

İbn Kesîr, Ebü'l-Fidâ' İmâdüddîn İsmâil b. Ömer b. Kesîr. Tefsîrü'l-Kur'âni'l-'azîm. thk. Mustafa es-Seyyid Muhammed vd. 15 Cilt. Kahire: Mektebetü Evlâdi'ş-Șeyh li't-Türâs, $1421 / 2000$.

İbnü'l-Arabî, Muhyiddin Muhammed b. Ali el-Arabî. Tefsîru İbni'l-'Arabî. b.y.: y.y., 1231/1816.

İbnü'l-Cevzî, Ebü'l-Ferec Abdurrahman b. Ali el-Bağdâdî. Zâdü'l-mesîr fì 'ilmi't-tefsîr. nşr. M. Züheyr eş-Şâviș. 9 Cilt. Beyrut: el-Mektebetü'l-İslâmî, 3. Basım, 1404/1984.

İsfehânî, Ebü'l-Kâsım Hüseyn b. Muhammed b. el-Mufaddal er-Râgıb. el-Müfredât fî garîbi'lKur'ân. nşr. Safvân Adnân Dâvûdî. Beyrut: ed-Dârü'ş-Şâmiyye, ts.

Kâşânî, Abdürrezzâk. Istılâhâtü's-sûfiyye. thk. Abdulâl Şâhîn. Kahire: Dâru'l-Menâr, $1413 / 1992$.

Kâşânî, Abdürrezzâk. Te’vîlâtü'l-Kur'ân. Riyad: Kral Soud Üniversitesi, Mahdûtât/Yazmalar, 2437, 1a-305a.

Kur'ân Yolu. Erişim 10 Nisan 2020. https://kuran.diyanet.gov.tr

Kurtubî, Ebû Abdullah Muhammed b. Ahmed. el-Câmi' li-ahkâmi'l-Kur'ân. thk. Abdullah b. Abdulmuhsin vd. 24 Cilt. Beyrut: Müessesetü'r-Risâle, 1427/2006.

Kutub, Seyyid. Fî Zılâli'l-Kur'ân. 6 Cilt. Kahire: Dâru'ş-Şurûk, 32. Basım, 1423/2003.

Kübrâ, Necmeddîn. et-Te'vîlâtü'n-Necmiyye. thk. Ahmed Ferîd el-Mezîdî. 6 Cilt. Beyrut: Dâru'lKütübi'l-'Ilmiyye, 1430/2009.

Makdisî, Mutahhar b. Tâhir. el-Bed've't-târîh. 6 Cilt. Kahire: Mektebetü’s-Sekâfe ed-Dîniyye, ts.

Mâtürîdî, Ebû Mansûr Muhammed b. Muhammed b. Mahmûd. Te'vîlâtüll-Kur'ân. thk. Ahmet Vanlıoğlu vd. 18 Cilt. İstanbul: Dâru'l-Mîzân, 1425-1427/2005-2007.

Mâverdî, Ebü'l-Hasen Alî b. Muhammed b. Habîb el-Basrî. en-Nüket ve'l-'uyûn. nşr. Seyyîd b. Abdülmaksûd b. Abdürrahîm. 6 Cilt. Beyrut: Dâru'l-Kütübi'l-'Ilmiyye, ts.

Meral, Yasin. "Mûsâ-Hızır Kıssası ve Kıssanın Yahudi Kökeniyle İlgili İddeaların Değerlendirilmesi”. Ankara Üniversitesi Illahiyat Fakültesi Dergisi 55/2 (2014), 129150.

Mukâtil b. Süleyman. Tefsîru Mukâtil b. Süleymân. thk. Abdullah Mahmûd Şehhâte. 5 Cilt. Beyrut: Müessesetü't-Târîhi'l-'Arabî, 1423/2002.

Müslim, Ebü'l-Hüseyn Müslim b. el-Haccâc. el-Câmi'u's-sahîh. nşr. Bedreddin Çetiner. 3 Cilt. İstanbul: Çağrı Yayınları, 2. Basım, 1413/1992.

Nehhâs, Ebû Ca'fer Ahmed b. Muhammed. Me'âni'l-Kur'âni'l-kerîm. thk. Muhammed Ali esSâbûnî. 6 Cilt. Mekke: Merkezü İhyâi't-Türâsi'l-İslâmî, 1408-1410/1988-1989.

Nîsâbûrî, Nizâmüddîn Hasen b. Muhammed. Garâi'bü'l-Kur'ân ve regâi'bü'l-furkân. nşr. Zekeriyyâ Umeyrât. 6 Cilt. Beyrut: Dâru'l-Kütübi'l-'Ilmiyye, 1416/1996.

Okuyan, Mehmet. Necmuddin Daye ve Tasavvufi Tefsiri. Samsun: Ondokuz Mayı Üniversitesi, Sosyal Bilimler Enstitüsü, Doktora Tezi, 1994.

Okuyan, Mehmet. "Necmeddîn-i Dâye". Türkiye Diyanet Vakfı İslâm Ansiklopedisi. Erişim 10 Temmuz 2020. https://islamansiklopedisi.org.tr/necmeddin-i-daye

Öztürk, Mustafa. "Bilge Kul-Musa Kıssası ve İslam Kültüründe Hızır Mitosu. "Ondokuz Mayıs Üniversitesi İlâhiyat Fakültesi Dergisi 14-15 (2003), 245-281.

Râzî, Fahreddin. Mefâtîhu'l-gayb: et-Tefsîru'l-kebîr. 32 Cilt. Beyrut: Dâru'l-Fikr, 1401/1981.

Sayın, Salih. Kelâm Açısından Kur'an ve Sünnette Hızır. Konya: Selçuk Üniversitesi, Sosyal Bilimler Enstitüsü, Yüksek Lisans Tezi, 2009. 
Semerkandî, Ebü'l-Leys Nasr b. Muhammed b. Ahmed. Tefsîrü'l-Kur'âni'l-Kerîm/Tefsîru Ebi'lLeys es-Semerkandî. thk. Ali Muhammed Muavvid vd. 3 Cilt. Beyrut: Dâru'l-Kütübi'l'Ilmiyye, 1422/2002.

Sülemî, Muhammed b. Hüseyin. Hakâiku't-Tefsîr. thk. Seyyid İmrân. 2 Cilt. Beyrut: Dâru'lKütübi'l-'Ilmiyye, 1421/2001.

Taberî, Ebû Ca'fer Muhammed b. Cerîr. Câmi'u'l-beyân 'an te'vîli âyi'l-Kur'ân. 30 Cilt. Beyrut: Dârü'l-Fikr, 1408/1988.

Taberî, Ebû Ca'fer Muhammed b. Cerîr. Târîhu'l-umem ve'l-mulûk. thk. Muhammed Ebu'l-Fadl İbrâhîm. 11 Cilt. Kahire: Dâru'l-Meârif bi-Mısr, 2. Basım, 1387/1967.

Temel, Zeynep. Kur'ân'daki Musa-Hızır Kıssasının İbnü'l-Arabî Yorumu. İstanbul: 29 Mayıs Üniversitesi, Sosyal Bilimler Enstitüsü, Yüksek Lisans Tezi, 2020.

Tirmizî, Ebû Îsâ Muhammed b. Îsâ. Sünenü't-Tirmizî. nşr. Bedreddin Çetiner. 5 Cilt. İstanbul: Çağrı Yayınları, 2. Basım, 1413/1992.

Uludağ, Süleyman. "Kaşânî, Abdürrezzâk". Türkiye Diyanet Vakfı İslâm Ansiklopedisi. Erişim 25 Ekim 2020. https://islamansiklopedisi.org.tr/kasani-abdurrezzak

Zeccâc, Ebû İshâk İbrâhîm b. es-Serî el-Bağdâdî. Me'âni'l-Kur'ân ve i'râbüh. thk. Abdülcelîl Abdüh Şelebî. 5 Cilt. Beyrut: Âlemü'l-Kütüb, 1408/1988.

Zemahşerî, Mahmûd b. Ömer. el-Keşşâf 'an hakâ'ikı gavâmizi't-tenzîl ve 'uyûni'l-ekâvîl fî vücûhi't-te'vîl. nşr. Halîl Me'mûn Șeyhâ. Beyrut: Dârü'l-Ma'rife, 3. Basım, 1430/2009.

Zerkeşî, Bedruddîn Muhammed b. Abdillah. el-Bürhân fí 'ulûmi'l-Kur'ân. thk. Muhammed Ebü'l-Fadl İbrâhîm. 4 Cilt. Kahire: Dâru't-Türâs, ts. 